\title{
1 Determining the slip rate and earthquake recurrence interval at the tip of a 2 foreberg in the Gobi-Altay, Mongolia
}

C.H. Lee ${ }^{\mathrm{a}}$, Y.B. Seong ${ }^{\mathrm{a}, *}$, J.-S. Oh ${ }^{\mathrm{a}}$

5

a Department of Geography, Korea University, Seoul 02841, Korea

\section{Abstract}

The Gobi-Altay, Mongolia, includes high mountain ranges that have accommodated the compressional stresses derived from the collision between the Eurasian and Indian plates. The Gurvan Bogd, which is one of the main mountain ranges in the Gobi-Altay, is a restraining bend along the sinistral Bogd Fault. Although surface ruptures did not form near the Artz Bogd during the $1957 \mathrm{M}_{\mathrm{w}} 8.1$ Gobi-Altay Earthquake, it is still active, as evidenced by a growing topography (i.e. forebergs). Six foreberg ridges have formed in the foreland of the Artz Bogd, which are considered to be the result of surface deformation of alluvial fans due to thrusting. One stream has cut down to expose a foreberg tip, providing the opportunity to explore the slip evolution of the region. Here we map a growing fault structure related to blind thrusting. We identify five faulting events from an analysis of the outcrop and apply optically stimulated luminescence dating to the faulted sedimentary layers, yielding an average slip rate of $0.045 \pm$ $0.007 \mathrm{~m} / \mathrm{kyr}$ and earthquake recurrence interval of $5.8 \pm 0.5 \mathrm{kyr}$ over the last $\sim 32 \mathrm{kyr}$. Furthermore, the 20 long-term ( $\sim 600 \mathrm{kyr})$ uplift rate of the foreberg is $0.067 \pm 0.007$ as deduced by dividing the vertical 21 displacement of the alluvial fan surface by the ${ }^{10} \mathrm{Be}$ surface exposure ages of boulders on the fan. The 22 discrepancy $(20 \%-30 \%)$ between these two deformation rates may be due to the different timescales they 23 cover and an along-strike gradient in slip rate.

\footnotetext{
* Corresponding author. E-mail address: ybseong@korea.ac.kr (Y.B. Seong)
} 


\section{Introduction}

Both large- and small-magnitude earthquakes have been observed in the Gobi-Altay, Mongolia, over the last century, and their locations and focal mechanisms have been mapped to elucidate regional earthquake processes (Dugarmaa et al., 2002; Demberel et al., 2011; Demberel and Anatoly, 2017). The distribution is localised along the Bogd Fault system and mountain-bounding faults of the Gurvan Bogd which is a mountain range consisting of three mountains such as Ihk Bogd, Baga Bogd, and Artz Bogd in the Gobi-Altay. The largest earthquake in the Gobi-Altay during the last century, the $1957 \mathrm{M}_{\mathrm{w}} 8.1$ GobiAltay Earthquake, also occurred along the Bogd Fault, near the Gurvan Bogd. A comprehensive analysis of the focal mechanisms around the Gobi-Altay Mountain Range has indicated predominantly strike-slip motion with NE-SW compression (Demberel and Anatoly, 2017).

Palaeoseismic information, such as fault geometry, focal mechanism, magnitude, and strain distribution, provides important insights into the local seismotectonic setting of a region. Estimates of fault slip rate and earthquake recurrence interval are the most fundamental components of palaeoseismic studies. Several studies have previously focused on forebergs (low ridges or hills that have formed due to thrusting; Florensov and Solonenko, 1963; Bayasgalan et al., 1999a, 1999b) in Mongolia to estimate the slip rates of regional faults and earthquake recurrence intervals (Owen et al., 1999; Ritz et al., 2003; Vassallo et al., 2005). These structures accommodate the compressional stresses that originate from the collision between the Eurasian and Indian plates. Therefore, identifying the geologic and geomorphic markers that capture the evolution of the NW-SE-striking forebergs in the Gobi-Altay, can yield the amount of far-field stress that is accommodated in an intraplate tectonic setting.

The previous palaeoseismological research approaches are based primarily on the age dating of faulted deposits. Numerous studies have applied radiocarbon analysis using charcoal or plant debris embedded in the sedimentary layers of fluvial deposits to determine the slip rate and earthquake recurrence interval (Weldon and Sieh, 1985; Niemi and Hall, 1992; Thompson et al., 2002; Lin et al., 2017). Cosmogenic radionuclide $\left({ }^{10} \mathrm{Be}\right.$ and $\left.{ }^{26} \mathrm{Al}\right)$ surface exposure dating has been applied to identify the age of geomorphic markers and constrain the local slip rate (Bierman et al., 1995; Ritz et al., 1995; van der Woerd et al., 2002, 2006; Seong et al., 2011). While luminescence dating is not a preferred method due to limitations such as incomplete bleaching before final deposition, which is commonly the case in high-density flow deposits, it is employed in conjunction with ${ }^{10} \mathrm{Be}$ surface exposure dating in arid regions owing to the absence of organic material for radiocarbon dating (Fattahi et al., 2006; Rizza et al., 2011).

Here we document the timing, occurrence, slip rate, and recurrence interval of an earthquake sequence 
56 at the tip of a foreberg along the Artz Bogd, Gobi-Altay, Mongolia. We applied optically stimulated 57 luminescence (OSL) dating to the faulted deposits in an excavated trench to determine the timing and slip 58 rate of faulting events over a short timescale $\left(10^{3}\right.$ to $\left.10^{4} \mathrm{yrs}\right)$. We also measured in situ-produced 59 cosmogenic ${ }^{10} \mathrm{Be}$ to date an alluvial fan surface that was deformed by a blind thrust, based on the 60 assumption that foreberg uplift reflects the cumulative vertical displacement, and determined the vertical 61 slip rate over a long timescale $\left(>10^{4} \mathrm{yrs}\right)$. These palaeoseismic analyses allowed us to infer earthquake 62 processes at short and long timescales in this region.

63 


\section{Study area}

The Bogd Fault, one of the main fault systems in Mongolia, is an approximately E-W-trending strikeslip fault with a minor dip-slip component, which developed along a slip line that was conditioned by the collision between the Indian and Eurasian plates (Fig. 1; Tapponnier and Molnar, 1976). It is a sinistral fault that contributed to the development of the Gobi-Altay Mountain Range in southern Mongolia (Bayasgalan et al., 1999a; Ritz et al., 2006). Gurvan Bogd (meaning 'three saint mountains' in Mongolian), which is the eastern segment of the Gobi-Altay Mountain Range, includes the Ikh Bogd, Baga Bogd, and Artz Bogd (Fig. 2). These three mountains occur at restraining bends on the Bogd Fault system, whereby the northern and southern margins of each mountain are bounded by strike-slip faults with a dip-slip (reverse) component, representing a flower structure (Bayasgalan et al., 1999a; Vassallo et al., 2007a).

The $1957 \mathrm{M}_{\mathrm{w}}$ 8.1 Gobi-Altay Earthquake occurred along the Bogd Fault in the western Gurvan Bogd, generating about $260 \mathrm{~km}$ of surface rupture to the north of the Ikh Bogd and Baga Bogd and causing a gigantic landslide in the Ikh Bogd range (Fig. 2; Florensov and Solonenko, 1963; Kurushin et al., 1997). However, the earthquake did not trigger any surface rupture or deformation along the mountain-bounding fault of the Artz Bogd, which maintains a right-stepping en echelon relationship with the Ikh Bogd and Baga Bogd (Bayasgalan et al., 1999b; Ritz et al., 2006).

The region around the Artz Bogd is still tectonically active, even though no surface deformation accompanied the 1957 earthquake. The Artz Bogd is the easternmost restraining bend in the Gobi-Altay Mountain Range. Its northern margin is bounded by N-vergent active thrusts and left-lateral oblique-slip faults, and its southern margin is bounded by S-vergent thrusts and left-lateral wrench zones, defining a flower structure (Cunningham, 1997). The river channels draining the mountain range have formed a large bajada in the foreland of the Artz Bogd, and several lines of small forebergs lie on this bajada (Fig. 3a). The forebergs developed via thrusting in the foreland of the mountain-bounding fault, and the thrusts dip toward the main mountain range (Florensov and Solonenko, 1963; Bayasgalan et al., 1999a; Owen et al., 1999). There are six forebergs in a left-stepping en echelon arrangement within the left-lateral shear zone near the Artz Bogd. The westernmost foreberg (FB1 in Fig. 3a) is located in the overlapping region of the Baga Bogd and Artz Bogd. Foreberg FB1 has different topographic features to the other five forebergs, possessing a southern slope that is much steeper than the northern slope. Forebergs FB2 and FB3 formed along S-dipping thrust faults, which are inferred to be faults that branched from the mountain-bounding fault of the Artz Bogd; the surface ruptures and fault scarps from these thrust faults 
95 are clearly observed on these forebergs (Bayasgalan et al., 1999a; Vassallo et al., 2005). There are no clear 96 ruptures or fault traces on and around the surfaces of forebergs FB4-FB6, except for one fault trace to the 97 northern side and the other one on the eastern side of foreberg FB6 (inset in Fig. 3a and inset in Fig. 3c).

98 The largest river in the region, Khovd Gol ('gol' means 'river' in Mongolian), drains the Artz Bogd to 99 the north, crossing a topographic low between forebergs FB5 and FB6. The river cuts the western tip of 100 foreberg FB6 (Fig. 3a and 3b), exposing a portion of the faulted structure (outcrop location in Fig. 3c). We 101 excavated a trench at this exposure and conducted a detailed analysis of the geometry and kinematics of 102 the fault and its relationship to the growth of foreberg FB6 to constrain the local palaeoseismic properties. 
104

105

106

107

108

109

110

\section{Methods}

\section{Luminescence dating}

We collected 12 samples for OSL dating from the faulted outcrop by inserting stainless steel and PVC pipes into the sedimentary layers in the outcrop (Fig. 4a). We obtained the samples from the uppermost sedimentary layers that were cut by each fault strand to constrain the maximum age of each faulting event. The samples were collected far from the section that was deformed via faulting or soft sediment deformation to avoid any earthquake-induced disturbance and derive the exact timing of deposition of each layer.

All of the pre-treatment and measurement procedures for OSL dating were conducted at the Korea Basic Science Institute (KBSI), Ochang, Korea. The coarse (90-250 $\mu \mathrm{m})$ quartz fraction was extracted from each sample via wet sieving and acid treatment. The separated grains were examined under infrared to confirm that feldspar grains had been removed. The infrared stimulated luminescence signals were negligible during the test, accounting for $<<10 \%$ of the blue-LED stimulated luminescence signals, which indicates the absence of feldspar contamination.

We used 168 -mm aliquots for each sample during the OSL signal measurements and employed the single-aliquot regenerative-dose (SAR) procedure for the equivalent dose estimation (Murray and Wintle, 2000; Table 1). The OSL signals were measured using an automated measurement system (Risø TL/OSLDA-20) at KBSI. The samples were irradiated during the first and fourth steps of the SAR procedure using a ${ }^{90} \mathrm{Sr} /{ }^{90} \mathrm{Y}$ beta source that was delivered at $0.086 \pm 0.001 \mathrm{~Gy} \cdot \mathrm{s}^{-1}$. The blue-LED stimulation light source $(470 \pm 30 \mathrm{~nm})$ was delivered at $\sim 101 \mathrm{~mW} \cdot \mathrm{cm}^{-2}$ to the sample position during the third and sixth steps to generate the luminescence signals. The stimulation was carried out for $40 \mathrm{~s}$ at $125^{\circ} \mathrm{C}$ to avoid charge retrapping, and the signals were detected using a 7-mm Hoya U-340 filter.

The dose rate of each sample was calculated based on the radionuclide concentrations that were measured via low-level high-resolution gamma spectrometry. The radionuclide concentrations were converted to dose rates using the dose rate conversion factors of Adamiec and Aitken (1998), and the beta attenuation factor was taken into account (Mejdahl, 1979). The dose rate was calibrated based on the water content in the sample (Aitken, 1985) and the cosmic ray contribution (Prescott and Hutton, 1994). 


\section{${ }^{10}$ Be surface exposure dating}

High-energy cosmic rays from our solar system and other galaxies regularly bombard the Earth and its atmosphere, and primarily react with atoms in the atmosphere, which subsequently produce various cosmogenic nuclides and a cascade of secondary cosmic rays. These secondary cosmic rays then react with the atoms in minerals on the exposed rock surfaces on Earth, producing in situ cosmogenic nuclides (e.g. ${ }^{3} \mathrm{He},{ }^{10} \mathrm{Be},{ }^{14} \mathrm{C},{ }^{21} \mathrm{Ne},{ }^{26} \mathrm{Al}$, and ${ }^{36} \mathrm{Cl}$ ) (Lal, 1991; von Blanckenburg, 2005). Cosmogenic surface exposure dating has therefore become one of the most commonly used and reliable numerical methods for dating various geomorphic surfaces, such as alluvial fans, fluvial and marine terraces, and moraines (Bierman et al., 1995; Nishiizumi et al., 2005; Granger, 2013).

We collected three samples from large boulders, which can be separated into two groups according to their locations on the alluvial fan, which belong to the northern limb of the foreberg FB6 (Figs. 3c and 3d), assuming that these boulders represent the depositional age of the alluvial fan surface. We chose large $(>1$ m) boulders to exclude the possibility of sampling material that was reworked or had otherwise migrated during sporadic intense precipitation and uplift due to faulting. However, we were unable to obtain a desirable number of boulder samples $(>5)$ because gravel and sand are the dominant fractions on the alluvial fan surface near foreberg F6. The samples were collected within $\sim 5 \mathrm{~cm}$ of each boulder surface. The sample locations were determined with a handheld global positioning system. Weathering information, such as lichen growth, varnishing, and pitting, was recorded, and the skyline was measured at $30^{\circ}$ intervals.

We conducted all of the chemical treatments on the samples at the Geochronology Laboratory, Korea University, following the community standard procedure for ${ }^{10} \mathrm{Be}$ extraction (Kohl and Nishiizumi, 1992; Seong et al., 2016). The samples were crushed, with the $250-500 \mu \mathrm{m}$ fractions separated via dry sieving. The sieved samples were first leached using a $\mathrm{HCl}-\mathrm{HNO}_{3}$ mixture to remove carbonate minerals and organic materials. They were then leached using a $\mathrm{HF}-\mathrm{HNO}_{3}$ mixture on heating roller for 9 hours to remove other minerals, such as feldspar and mica. We removed the magnetic minerals and reprecipitated fluoride with a magnet and handpicking, respectively, between two leaching processes. The entire process yielded $\sim 15 \mathrm{~g}$ of pure quartz for each sample. The quartz samples were spiked using a ${ }^{9} \mathrm{Be}$ carrier with a low background ${ }^{10} \mathrm{Be}$ level and dissolved in a highly concentrated $\mathrm{HF}$ and $\mathrm{HNO}_{3}$ mixture on a hotplate. The fluoride was then removed via $\mathrm{HNO}_{3}$ and $\mathrm{HClO}_{4}$ fuming, and $\mathrm{Be}$ was separated using an ion exchange column, where it was separated at $\mathrm{pH}>7$. Be was precipitated as $\mathrm{BeOH}$ in $\mathrm{NH}_{4} \mathrm{OH}$. The $\mathrm{BeOH}$ in the quartz crucible was dried in a warm $\left(\sim 80^{\circ} \mathrm{C}\right)$ bath and then calcined into $\mathrm{BeO}$ at $800^{\circ} \mathrm{C}$ for 10 
163 minutes to remove water and ammonium salt. We mixed the resultant $\mathrm{BeO}$ with niobium powder to form 164 the targets. The targets were measured using a $6 \mathrm{MV}$ accelerator mass spectrometer at Korea Institute of 165 Science and Technology, Seoul, Korea.

166 The measured ${ }^{10} \mathrm{Be} /{ }^{9} \mathrm{Be}$ ratios were normalised to a ${ }^{10} \mathrm{Be}$ standard $\left(5-1 ; 2.709 \times 10^{-11}{ }^{10} \mathrm{Be} /{ }^{9} \mathrm{Be}\right)$ prepared 167 by Nishiizumi et al. (2007) using a ${ }^{10} \mathrm{Be}$ half-life of $1.38 \times 10^{6}$ years (Chmeleff et al., 2010; Korschinek et 168 al., 2010), and converted into ${ }^{10} \mathrm{Be}$ concentrations after correcting the ratios with a process blank $(2.679 \times$ $\left.16910^{-15} \pm 1.120 \times 10^{-15}{ }^{10} \mathrm{Be} /{ }^{9} \mathrm{Be}\right)$. We then calculated the ${ }^{10} \mathrm{Be}$ surface exposure ages using the CRONUS170 Earth online calculator version 3.0 (Balco et al., 2008); the resultant exposure ages are listed in Table 3. 
172

173

174

175

176

177

178

179

180

181

182

183

184

185

186

187

188

189

190

191

192

193

194

195

196

197

198

199

\section{Results}

\section{Trench}

We identified 23 layers in the trench (Fig. 4a). The grain size distribution in the trench wall was predominantly in the silt to sand size range $(0.2-200 \mu \mathrm{m})$, although there were angular to subangular pebble clasts in the silt-sand matrix, particularly in layers L1, L6, L8, L12, L16, and L20. Layers L1, L16, and L20 are matrix-supported, whereas layers L6, L8, and L12 are clast-supported, which is indicative of sheet-flow deposits. A thick ( $\sim 20 \mathrm{~cm})$ carbonate layer (L22) caps the sedimentary layer (L21) and is overlain by a $\sim 20$-cm-thick matrix-supported sheet-flow deposit (L23). Most of the layers display some type of bedding, although layers L2, L3, L13, L15, L17, L18, L19, and L21 are massive in structure.

Total 23 layers were observed, and eight main fault strands (F1-F8) were identified in the trench wall (Fig. 4b). We divided all layers in the trench into nine deformation units based on the observed deformation along each fault strand, with the uppermost layer of each unit marking the uppermost layer that was cut by a given fault strand; note that L22 and L23 were not cut by any fault strands, which belong to deformation unit 9. The uppermost layers are layers L3, L7, L8, L10, L14, L19, L20, and L21. The fault strands all possess a similar orientation, striking $\mathrm{N} 60-86^{\circ} \mathrm{W}$ and dipping $61-70^{\circ} \mathrm{SW}$, with the dip decreasing toward the surface $\left(30-52^{\circ} \mathrm{SW}\right)$. The faults have an almost pure dip-slip (reverse) component, with a small strike-slip (sinistral) component, as shown by the orientation of slickenlines (Fig. $4 \mathrm{c}$ ), which have a rake angle of $87-89^{\circ} \mathrm{N}$ in the clockwise direction with respect to the fault strike.

The trench orientation was $\mathrm{N} 20-30^{\circ} \mathrm{E}$, almost normal to the fault strike. The dip separations and vertical displacements were measured at the boundary of layers L2 and L3, as bedrock was not present in the footwall, and the boundary between layers L1 and L2 was not clear in some parts of the trench. Example piercing points that we referenced are marked by the characters in black squares in Fig. $4 \mathrm{~b}$. The dip separation and vertical displacement (values in parentheses) between $\mathrm{a}-\mathrm{a}$ ', b- $\mathrm{b}^{\prime}$, and c-c' are $0.34 \mathrm{~m}$ $(0.27 \mathrm{~m}), 0.62 \mathrm{~m}(0.41 \mathrm{~m})$, and $0.50 \mathrm{~m}(0.47 \mathrm{~m})$, respectively, with each displacement having a measurement error of $10 \%$, as the trench was excavated almost normal to the fault strike, and slickenlines indicate almost pure dip-slip movement. 


\section{Luminescence dating}

The equivalent dose was calculated following the central age model estimation (Galbraith et al., 1999), and the depositional timing of each layer was calculated by dividing the equivalent dose by the annual dose rate for each sample (Table 2). OSL samples ABA4-OL-03, -07, -08, -10, -14, -19, and -21 were collected from the uppermost layers that were cut by the fault strands. We could not insert an OSL pipe into layer L20 to collect a sample due to the presence of numerous large pebble clasts. The oldest uppermost layer cut by the fault was layer L3, which was deposited at $32.34 \pm 3.72 \mathrm{ka}$, and the youngest was layer L21, which was deposited at $9.86 \pm 0.60 \mathrm{ka}$.

The OSL dating results show inversion in some sections of the trench, although we did not observe any evidence of stratigraphic inversion to support these results. Incomplete bleaching of the luminescence signal prior to final deposition can result in an overestimate the depositional age (Alexanderson and Murray, 2012; Yang et al., 2012), whereas depositional disturbances due to soil-forming processes, earthquake shaking, plant roots, and tunnelling by ants and rodents can result in an underestimate of the age (Stevens et al., 2006). For example, the measured age of layer L3 is younger than that of layer L7, even though layer L3 is lower than layer L7. An overestimation due to incomplete bleaching may arise because of the depositional environment or the physical properties of the sedimentary deposits (Alexanderson and Murray, 2012). Fluvial deposits are likely to contain both well-bleached grains and insufficiently bleached grains, as they are mixed and transported by water (Murray et al., 1995; Olley et al., 1998; Galbraith et al., 1999). Furthermore, it is possible for the sediments in sedimentary layers that were deposited by a highly concentrated massive flow to be only partially bleached during deposition. These deposits usually have either an unsorted texture, massive structure or no clear sedimentary structures. Therefore, we interpreted that the mass flow deposits in the trench might be incompletely bleached, yielding overestimated ages. We performed a regression analysis to resolve the age inversion problem, where we derived a linear relationship between the depths and ages of the layers under the assumption of a constant depositional rate (Fig. 5; Table 2). 


\section{${ }^{10} \mathrm{Be}$ surface exposure dating}

Three samples were collected from boulder surfaces to constrain the age of the alluvial fan (Figs. 3c and 3d). The sampled boulders were red-coloured conglomerate.

The boulders were likely sourced from the Artz Bogd and transported during formation of the alluvial fan. There should be many boulders near foreberg FB6 if they were sourced from the foreberg itself (i.e. reworked) or had an in situ origin. However, there are few boulders in and around foreberg FB6. Furthermore, the bedrock around the Artz Bogd includes conglomerate and red beds (Cunningham et al., 1997), and we observed many boulder- and cobble-sized blocks of red-coloured conglomerate in the valley bottom along the Artz Bogd and near the apex of the alluvial fan. The boulders that we sampled on foreberg FB6 may have been deposited during the formation of the alluvial fan and subsequently uplifted due to thrusting forming the foreberg. Therefore, we believe that ${ }^{10} \mathrm{Be}$ surface exposure dating of the boulders can constrain the age of the alluvial fan surface.

The boulder ages can be separated into two groups based on their locations (Fig. 8; Table 3). The first group includes two samples, $\mathrm{ABC} 001$ and $\mathrm{ABC} 002$, which have similar exposure ages of $40.7 \pm 3.2 \mathrm{ka}$ and $43.8 \pm 3.5 \mathrm{ka}$, respectively. The second group includes only one sample (ABC004), which has an exposure age of $612.7 \pm 61.6 \mathrm{ka}$. The difference between the ages of these two groups is extremely large (>500 kyr). Given the site-specific conditions of the two sites and previous reports on the antiquity of mountain surface of potential candidate source of alluvial fan in the region (Vassallo et al., 2007b; Oh et al., 2019), the older sample on the original, gentler surface may indicate the true depositional age of the alluvial fan rather than those on the uplifted hill. This discrepancy is considered in the discussion. 


\section{Discussion}

\section{Timing of faulting}

The OSL ages of the sedimentary layers represent the timing of deposition. Layers L3, L7, L8, L10, L14, L19, L20, and L21 are the uppermost layers cut by faults F1-F8, respectively. The OSL age of the uppermost layer for a given deformation unit generally indicates the maximum age of that faulting event, and the OSL age of the overlying unit defines the minimum age of the following event, since the faulting event in a given unit is assumed to occur after the deposition of its uppermost layer and before the deposition of the overlying unit, and each fault is assumed to cut the entire unit during faulting. All of the faults, except for faults F3 and F4, are interpreted to have cut the entire unit. However, the timings of the faulting events along faults F6 and F7 cannot be constrained based on this hypothesis because we do not have age data for unit 7. We therefore treat unit 7 as a gap between the ages of units 6 and 8 (Fig. 6a).

However, if a given fault did not cut the entire unit, then there should be fault-induced deformation, such as folding or soft sediment deformation, in the intact layers. The maximum age of the faulting event is the age of the intact layer including folding structure in this case, and the minimum age can be constrained by the age of the overlying unit. We interpreted that unit 4 had already been deposited when the faulting along fault F3 occurred because fault F3 cut through unit 4 but did not cut into unit 4, while unit 4 was folded by fault F3 (a black empty box in Fig. 4b). Therefore, we interpret that the F3 faulting event occurred between the deposition of units 4 and 5 (Fig. 6a).

We also interpret that the F4 faulting event occurred between the deposition of units 5 and 6 (Fig. 6a), as fault F4 cut through unit 4 but did not cut into unit 5. However, it is difficult to determine whether the F3 and F4 faulting events occurred simultaneously based on their fault geometries and a potential relationship between the two faults. Fault F4 branched from a different fault strand to fault F3, whereas it branched from the same fault strand as fault F5. Strain localizes along the fault plane when a fault is active. Therefore, when fault F3 was active, the strain localised along the F3 fault plane, such that it was less likely for fault F4 to activate contemporaneously with fault F3. It is worth noting that the faults in this trench define a $\mathrm{N}$-vergent thrust system in a break-back sequence, which implies that the younger faults developed in the hanging walls of the older faults. Therefore, we prefer to interpret that faults F4 and F5 branched from the same fault strand and were active simultaneously, based on the geometrical properties of the faults (Fig. 6). 


\section{Palaeoseismic implications}

We first estimated the slip rate and earthquake recurrence interval based on the true displacement of the sedimentary layers in the trenched wall and the timing of each faulting event. We then constructed a model for the faulting events by restoring the events in an inverse order during the late Quaternary.

The slip rate was calculated by dividing the cumulative displacement by the age of the displaced layer since it was derived from the total slip amount for the five faulting events. We calculated the slip rate using the cumulative true displacement of layer L3 and the fitted age of layer L3. The cumulative true displacement of layer L3 is $1.46 \pm 0.14 \mathrm{~m}$ (considering $10 \%$ of measurement error), and its fitted OSL age is $32.49 \pm 3.72 \mathrm{ka}$ (Fig. 4b; Table 2), yielding a cumulative slip rate of $0.045 \pm 0.007 \mathrm{~m} / \mathrm{kyr}$. Our slip rate is similar to Owen et al.'s (1999) cumulative rate of $0.050 \pm 0.003 \mathrm{~m} / \mathrm{kyr}$ based on one OSL age of the deformed, oldest layer and a pure thrust geometry in a natural exposure.

We identified five faulting events and constructed a model for the sequence of events (Fig. 7) based on the timing of the events (Fig. 6). The first faulting event occurred along fault F1 between 32.49 and 23.57 ka. The second took place between 23.57 and $21.02 \mathrm{ka}$ along faults F2 and F3. The third event occurred between 21.02 and $12.96 \mathrm{ka}$ along faults F4 and F5, and the fourth between 12.96 and 9.56 ka along faults F6 and F7. The final event took place along fault F8 after $9.56 \mathrm{ka}$. We then estimated the earthquake recurrence interval based on the central age of each event, yielding $\sim 5.8 \pm 0.5 \mathrm{kyr}$ for the last $32 \mathrm{kyr}$ (Fig. $6 b)$. 


\section{Estimation of the long-term deformation rate}

We estimated the uplift rate of foreberg FB6 (Fig. 3) under the assumption that the foreberg developed via faulting after the alluvial fan was deposited. The uplift rate was calculated by dividing the amount of foreberg uplift by the age of the undeformed alluvial fan surface.

The amount of foreberg uplift was derived from a high-resolution $(0.5 \mathrm{~m} / \mathrm{pixel})$ digital elevation model (DEM) that was generated using 7000 aerial images acquired by a drone (DJI Phantom 4 pro) in June 2018. We acquired a series of cross-sectional profiles around the boulder sampling sites (Figs. 3 and 8) and restored the original surface of the alluvial fan by fitting the undeformed alluvial fan surface. The fitted surface possessed a slope of $\sim 1^{\circ}$, which is indicative of flat alluvial fans (Blissenbach, 1954). The amount of uplift was estimated by subtracting the elevation of the restored fan surface from the foreberg elevation, which indicates the vertical displacement between the deformed and original surfaces. The maximum amount of uplift is $41.0 \pm 0.8 \mathrm{~m}$.

The boulders can be separated into two groups based on their locations (Fig. 8), as previously mentioned. The first group ( $\mathrm{ABC} 001$ and $\mathrm{ABC} 002)$ is on the top of a small, uplifted hill, which is an incipient foreberg, and show ages of $40.7 \pm 3.2 \mathrm{ka}$ and $43.8 \pm 3.5 \mathrm{ka}$. The second group (ABC004) lies on the original, flat alluvial fan surface and has an age of $612.7 \pm 61.6 \mathrm{ka}$. The boulders in the first group may have been toppled or overturned during the uplift due to thrusting, such that they yield an underestimate of the age of the alluvial fan surface. Therefore, the boulder in the second group may indicate the true timing of deposition. It is worth noting that the old age ( $\sim 600 \mathrm{kyr})$ of the alluvial fan surface in our study region is similar to other ages reported in and around the Gurvan Bogd (Vassallo et al., 2007b, 2011; Oh, et al., 2019).

We estimated the long-term uplift rate of foreberg FB6 from the amount of foreberg uplift and the ${ }^{10} \mathrm{Be}-$ dervied age of the alluvial fan surface, which is $0.067 \pm 0.007 \mathrm{~m} / \mathrm{kyr}$. Our calculated slip rate is largely in agreement with previous results. Owen et al. (1999) derived a vertical slip rate of $0.050 \pm 0.003 \mathrm{~m} / \mathrm{kyr}$ based on displaced sedimentary layers and their ages for foreberg FB6. Vassallo et al. (2005) derived a slip rate of $0.13 \pm 0.01 \mathrm{~m} / \mathrm{kyr}$ based on a displaced surface and its age for foreberg FB2 (Figs. 2 and 3a), which lies near the Artz Bogd. Numerous studies have been conducted on the forebergs along the Bogd Fault, which is the main fault in the region, and near the Ikh Bogd and Baga Bogd, with vertical slip rates ranging from $0.10 \pm 0.01$ to $0.23 \pm 0.05 \mathrm{~m} / \mathrm{kyr}$ (Fig. 2; Hanks et al., 1997; Carretier, 2000; Ritz et al., 2003; Vassallo et al., 2005). Given that the vertical slip rates from those studies were obtained near the Bogd Fault, whereas our study area is distal to the Bogd Fault, we would expect our slip rate to be lower 
330 because the slip rate decreases toward the fault tip. Therefore, we interpret our uplift rate of $0.067 \pm 0.007$ $331 \mathrm{~m} / \mathrm{kyr}$ for foreberg FB6 as a reasonable estimate.

332 However, this uplift rate is based on the displaced geomorphic surface and its age, which is inconsistent 333 with the slip rate that we estimated from the trench. The long-term uplift rate is $0.067 \pm 0.007 \mathrm{~m} / \mathrm{kyr}_{2}$ and 334 the vertical slip rate is $0.045 \pm 0.005 \mathrm{~m} / \mathrm{kyr}$. This discrepancy may result from (1) the different timescales 335 for the short-term and long-term uplift rates, and (2) the different locations where the slip rate calculations 336 were made.

337 The timescale for the slip rate derived from the trench only covers the past $\sim 32 \mathrm{ka}$, which is the age of 338 the oldest layer in the section, whereas the uplift rate based on the geomorphic surface covers the past $339 \sim 612.7 \mathrm{ka}$, which is the age of the undeformed alluvial fan surface. Therefore, it can be interpreted that 340 the long-term uplift rate over the past $\sim 612.7 \mathrm{ka}$ is higher than the short-term slip rate that spans the past $341 \sim 35.03 \mathrm{ka}$. Furthermore, the trench is located at the tip of foreberg FB6, whereas the alluvial fan surface 342 that is used for the vertical growth measurement and ${ }^{10} \mathrm{Be}$ exposure dating is $\sim 700 \mathrm{~m}$ away from the tip. 343 The slip rate generally exhibits a gradual decrease toward both tips along the fault strike, reaching a 344 maximum at the centre. This trend suggests that the discrepancy between these two rates can be explained 345 by a slip rate gradient along the fault strike. 


\section{Conclusion}

349 We conducted a palaeoseismic study on a foreberg that has grown on an alluvial fan that drains the Artz 350 Bogd and preserves fundamental information on the frequency of earthquakes and their associated slip in 351 the Gobi-Altay, Mongolia. Forebergs grow both vertically and laterally on the alluvial fan surface when 352 thrusting either propagates or branches from the mountain-bounding fault, forming the main fault system 353 in the study area. The main conclusions are as follows.

354 1) We identified eight fault strands in a trenched outcrop containing 23 sedimentary layers and bedrock 355 at the western tip of the foreberg. We identified five faulting events based on the stratigraphic sequence, 356 cutting relationships, and timing of faulting along these fault strands.

357 2) We estimated a cumulative slip rate of $0.045 \pm 0.007 \mathrm{~m} / \mathrm{kyr}$ and an earthquake recurrence interval of $3585.8 \pm 0.5 \mathrm{kyr}$ for the past $\sim 32 \mathrm{kyr}$ based on the displacement of sedimentary layers and their OSL ages.

359 3) The long-term ( 600 kyr) uplift rate is $0.067 \pm 0.007 \mathrm{~m} / \mathrm{kyr}$, which we determined by dividing the 360 vertical displacement of the geomorphic surface (alluvial fan surface) by the ${ }^{10} \mathrm{Be}$-derived age of the alluvial fan.

4) These inconsistent vertical growth rates of the foreberg may be due to the different time scales they cover and a gradient in slip rate along the fault strike of the foreberg. 


\section{Acknowledgements}

366 This work was supported by the Ministry of Education of the Republic of Korea and the National

367 Research Foundation of Korea (grant NRF-2018S1A5A2A01031348 awarded to Y.B.Seong). We are in

368 debt to Dr. Hong with the help on interpretation of OSL dating and P. Khandsuren for her help in field.

369 We express sincere thanks to two anonymous reviewers for their constructive and helpful comments.

370

371

372 
373

374

375

376

377

378

379

380

381

382

383

384

385

386

387

388

389

390

391

392

393

394

395

396

397

398

399

\section{References}

Aitken, M. J., 1985. Thermoluminescence dating. Academic Press, London.

Adamiec, G., and Aitken, M., 1998. Dose-rate conversion factors: update. Ancient TL 16 (2), 37-50.

Alexanderson, H., and Murray, A. S., 2012. Problems and potential of OSL dating Weichselian and Holocene sediments in Sweden. Quaternary Science Reviews 44, 37-50.

Balco, G., Stone, J. O., Lifton, N. A., Dunai, T. J., 2008. A complete and easily accessible means of calculating surface exposure ages or erosion rates from ${ }^{10} \mathrm{Be}$ and ${ }^{26} \mathrm{Al}$ measurements. Quaternary Geochronology 3, 174-195.

Bayasgalan, A., Jackson, J., Ritz, J. -F., Carretier, S., 1999a. 'Forebergs', flower structures, and development of large intra-continental strike-slip faults: the Gurvan Bogd fault system in Mongolia. Journal of Structural Geology 21, 1285-1302.

Bayasgalan, A., Jackson, J., Ritz, J. -F., Carretier, S., 1999b. Field examples of strike-slip fault terminations in Mongolia and their tectonic significance. Tectonics 18 (3), 394-411.

Bierman, P. R., Gillespie, A. R., Caffee, M. W., 1995. Cosmogenic Ages for Earthquake Recurrence Intervals and Debris Flow Fan Deposition, Owens Valley, California. Science 270, 447-450.

von Blanckenburg, F., 2005. The control mechanisms of erosion and weathering at basin scale from cosmogenic nuclides in river sediment. Earth and Planetary Science Letters 237, 462-479.

Blissenbach, E., 1954. Geology of alluvial fans in semiarid regions. Geological Society of America Bulletin 65, 175-190.

Carretier, S., 2000. Cycle sismique et surrection de la chaîne de Gurvan Bogd (Mongolie): approche de la géomorphologie quantitative [in French]. Université de Montpellier 2, pp. 324.

Chmeleff, J., von Blanckenburg, F., Kossert, K., Jakob, D., 2010. Determination of the ${ }^{10}$ Be half-life by multicollector ICP-MS and liquid scintillation counting. Nuclear Instruments and Methods in Physics Research Section B: Beam Interactions with Materials and Atoms 268 (2), 192-199.

997 Cunningham, W. D., Windley, B. F., Owen, L. A., Barry, T., Dorjnamjaa, D., Badamgarav, J., 1997.

98 Geometry and style of partitioned deformation within a late Cenozoic transpressional zone in the eastern Gobi Altai Mountains, Mongolia. Tectonophysics 277, 285-306. 
400

Demberel, S., Radziminovich, N., Bayaraa, G., Munkhuu, U., Davaasuren, G., Danzonsan, E., Radziminovich, Y., Mordvinova, V. M., Battsetseg, B., 2011. Focal Mechanisms of Earthquakes in Mongolia. American Geophysical Union, Fall Meeting, Abstract \#S11B-2206.

Demberel, S. and Anatoly, V. K., 2017. Lithospheric stress in Mongolia. Geoscience Frontier 8, 13231337.

Durgarmaa, T., Schlupp, A., Adija, M., Ankhtsetseg, D., Bayaraa, G., Munkhuu, D., Selenge, L., Tsembel, B., Ulziibat, M., Odonbaatar, C., Mungunsuren, D., Munkhsaihan, A., Narantsetseg, R., Urtnasan, K., Bayarsaikhan, C., Baasanbat, T., 2002. Seismic Map of Mongolia and Site Effect Microzoning at the Capital, Ulaanbaatar. American Geophysical Union, Fall Meeting, Abstract \#S71B-1100.

Fattahi, M., Walker, R., Hollingsworth, J., Bahroudi, A., Nazari, H., Talebian, M., Armitage, S., Stokes, S., 2006. Holocene slip-rate on the Sabzevar thrust fault, NE Iran, determined using optically stimulated luminescence (OSL). Earth and Planetary Science Letters 245, 673-684.

Florensov,N. A., and Solonenko, V. P., 1963. The Gobi-Altai earthquake [in Russian]. Akad. Nauk, Moscow, pp. 391. [English translation, 1965. Isr. Program for Sci. Transl., Jerusalem, pp. 424]

Galbraith, R. F., Roberts, R. G., Laslett, G. M., Yoshida, H., Olley, J. M., 1999. Optical dating of single and multiple grains of quartz from Jinmium rock shelter, Northern Australia: Part I, Experimental design and statistical models. Archaeometry 41 (2), 339-364.

Granger, D. E., Lifton, N. A., Willenbring, J. K., 2013. A cosmic trip: 25 years of cosmogenic nuclides in geology. Geological Society of America Bulletin 125, 1379-1402.

Hanks, T. C., Ritz, J. F., Kendrick, K. J., Finkel, R. C., Garvin, C. D., 1997. Uplift rates in a continental interior: faulting offsets of a $\sim 100 \mathrm{ka}$ abandoned fan along the Bogd fault, southern Mongolia. Proceedings of the Penrose Conference on the Tectonics of Continental Interiors.

Kohl, C. P., Nishizumi, K., 1992. Chemical isolation of quartz for measurement of in-situ-produced cosmogenic nuclides. Geochimica et Cosmochimica Acta 56, 3583-3587.

Korschinek, G., Bergmaier, A., Faestermann, T., Gerstmann, U. C., Knie, K., Rugel, G., Wallner, A., Dillmann, I., Dollinger, G., Lierse von Gostomski, Ch., Kossert, K., Maiti, M., Poutivtsev, M., Remmert, A., 2010. A new value for the half-life of ${ }^{10} \mathrm{Be}$ by Heavy-Ion Elastic Recoil Detection and liquid scintillation counting. Nuclear Instruments and Methods in Physics Research Section B: Beam Interactions with Materials and Atoms 268 (2), 187-191. 
Kurushin, R. A., Bayasgalan, A., Ölziybat, M., Enhtuvshin, B., Molnar, P., Bayarsayhan, Ch., Hudnut, K. W., Lin, J., 1997. The Surface Rupture of the 1957 Gobi-Altay, Mongolia, Earthquake. Geological Society of America Special Paper 320.

Lal, D., 1991. Cosmic ray labeling of erosion surfaces: in situ nuclide production rates and erosion models. Earth and Planetary Science Letters 104, 424-439.

Lin, A., Chen, P., Satsukawa, T., Sado, K., Takahashi, N., Hirata, S., 2017. Millennium Recurrence Interval of Morphogenic Earthquakes on the Seismogenic Fault Zone that triggered the $2016 \mathrm{M}_{\mathrm{w}} 7.1$ Kumamoto Earthquake, Southwest Japan. Bulletin of the Seismological Society of America 107 (6), 2687-2702.

Mejdahl, V., 1979. Thermoluminescence dating: Beta-dose attenuation in quartz grains. Archaeometry 21 (1), 61-72.

Murray, A. S., Olley, J. M., Caitcheon, G. G., 1995. Measurement of equivalent doses in quartz from contemporary water-lain sediments using optically stimulated luminescence. Quaternary Science Reviews 14 (4), 365-371.

Murray, A. S., and Wintle, A. G., 2000. Luminescence dating of quartz using an improved single-aliquot regenerative-dose protocol. Radiation Measurements 32 (1), 57-73.

Niemi, T. M., and Hall, N. T., 1992. Late Holocene slip rate and recurrence of great earthquakes on the San Andreas fault in northern California. Geology 20, 195-198.

Nishiizumi, K., Caffe, M. W., Finkel, R. C., Brimhall, G., Mote, T., 2005. Remnants of fossil alluvial fan landscape of Miocene age in the Atacama Desert of northern Chile using cosmogenic nuclide exposure age dating. Earth and Planetary Science Letters 237, 499-507.

Nishiizumi, K., Imamura, M., Caffe, M. W., Southon, J. R., Finkel, R. C., McAninch, J., 2007. Absolute calibration of ${ }^{10} \mathrm{Be}$ AMS standards. Nuclear Instruments and Methods in Physics Research B 258 (2), 403413.

Olley, J., Caitcheon, G., Murray, A., 1998. The distribution of apparent dose as determined by optically stimulated luminescence in small aliquots of fluvial quartz: Implications for dating young sediments. Quaternary Science Reviews 17 (11), 1033-1040.

Oh, J. -S., Seong, Y. B., Khandsuren, P., Yu, B. Y., 2019. Formation and Glacial History of Ikh Bogd in Gobi-Altay, Mongolia. Annual meeting of the Korean Geomorphological Association, 30-31. 
Owen, L. A., Cunningham, D., Richards, B. W. M., Rhodes, E., Windley, B. F., Dorjnamjaa, D., Badamgarav, J., 1999. Timing of formation of forebergs in the northeastern Gobi Altai, Mongolia: implications for estimating mountain uplift rates and earthquake recurrence intervals. Journal of the Geological Society, London 156, 457-464.

Prescott, J. R. and Hutton, J. T., 1994. Cosmic ray contributions to dose rates for luminescence and ESR dating: Large depths and long-term time variations. Radiation Measurements 23, 497-500.

Ritz, J. F., Brown, E. T., Bourlès, D. L. Philip, H., Schlupp, A., Raisbeck, G. M., You, F., Enkhtuvshin, B., 1995. Slip rates along active faults estimated with cosmic-ray-exposure dates: Application to the Bogd fault, Gobi-Altaï, Mongolia. Geology 23 (11), 1019-1022.

Ritz, J. -F., Bourlès, D., Brown, E. T., Carretier, S., Chéry, J., Enhtuvshin, B., Galsan, P., Finkel, R. C., Hanks, T. C., Kendrick, K. J., Philip, H., Raisbeck, G., Schlupp, A., Schwartz, D. P., Yiou, F., 2003. Late Pleistocene to Holocene slip rates for the Gurvan Bulag thrust fault (Gobi-Altay, Mongolia) estimated with ${ }^{10} \mathrm{Be}$ dates. Journal of Geophysical Research 108 (B3), 2162.

Ritz, J. -F., Vassallo, R., Braucher, R., Brown, E. T., Carretier, S., Bourlès, D. L., 2006. Using in situproduced ${ }^{10} \mathrm{Be}$ to quantify active tectonics in the Gurvan Bogd mountain range (Gobi-Altay, Mongolia). Geological Society of America Special Paper 415, 87-110.

Rizza, M., Mahan, S., Ritz, J. -F., Nazari, H., Hollingsworth, J., Salamati, R., 2011. Using luminescence dating of coarse matrix to estimate the slip rate of the Astaneh fault, Iran. Quaternary Geochronology 6, 390-406.

Seong, Y. B., Kang, H. C., Ree, J. -H., Yi, C., Yoon, H., 2011. Constant slip rate during the late Quaternary along the Sulu He segment of the Altyn Tagh Fault near Changma, Gansu, China. Island Arc 20, 94-106.

Seong, Y. B., Dorn, R. I., Yu, B. Y., 2016. Evaluating the life expectancy of a desert pavement. EarthScience Reviews 162, 129-154.

Stevens, T., Armitage, S. J., Lu, H., Thomas, D. S. G., 2006. Sedimentation and diagenesis of Chinese loess: Implications for the preservation of continuous, high-resolution climate records. Geology 34(10), 849-852.

Stone, S. O., 2000. Air pressure and cosmogenic isotope production. Journal of Geophysical Research 105 (B10), 23,753-23,759. 
487

488

489

490

491

492

493

494

495

496

497

498

499

500

501

502

503

504

505

506

507

508

509

510
Tapponnier, P. and Molnar, P., 1976. Slip-line field theory and large-scale continental tectonics. Nature 264, 319-324.

Thompson, S. C., Weldon, R. J. Rubin, C. M., Abdrakhmatov, K., Molnar, P., Berger, G. W., 2002. Late Quaternary slip rates across the central Tien Shan, Kyrgyzstan, central Asia. Journal of Geophysical Research 107 (B9), 2203.

van der Woerd, J., Tapponnier, P., Ryerson, F. J., Meriaux, A. -S., Meyer, B., Gaudemer, Y., Finkel, R. C., Caffee, M. W., Guoguang, Z., Zhiqin, X., 2002. Uniform postglacial slip-rate along the central 600 $\mathrm{km}$ of the Kunlun Fault (Tibet), from ${ }^{26} \mathrm{Al},{ }^{10} \mathrm{Be}$, and ${ }^{14} \mathrm{C}$ dating of riser offsets, and climatic origin of the regional morphology. Geophysical Journal International 148, 356-388.

van der Woerd, J., Klinger, Y., Sieh, K., Tapponnier, P., Ryerson, F. J., Mériaux, A. -S., 2006. Long-term slip rate of the southern San Andreas Fault from ${ }^{10} \mathrm{Be}-{ }^{26} \mathrm{Al}$ surface exposure dating of an offset alluvial fan. Journal of Geophysical Research 111, B04407.

Vassallo, R., Ritz, J. -F., Braucher, R., Carretier, S., 2005. Dating faulted alluvial fans with cosmogenic ${ }^{10} \mathrm{Be}$ in the Gurvan Bogd mountain range (Gobi-Altay, Mongolia): climatic and tectonic implications. Terra Nova 17, 278-285.

Vassallo, R., Ritz, J. -F., Braucher, R., Jolivet, M., Carretier, S., Larroque, C., Chauvet, A., Sue, C., Todbileg, M., Bourlès, D., Arzhannikova, A., Arzhannikov, S., 2007a. Transpressional tectonics and stream terraces of the Gobi-Altay, Mongolia. Tectonics 26, TC5013.

Vassallo, R., Jolivet, M., Ritz, J. -F., Braucher, R., Larroque, C., Sue, C., Todbileg, M., Javkhlanbold, D., 2007b. Uplift age and rates of the Gurvan Bogd system (Gobi-Altay) by apatite fission track analysis. Earth and Planetary Science Letters 259, 333-346.

Vassallo, R., Ritz, J. -F., Carretier, S., 2011. Control of geomorphic processes on ${ }^{10}$ Be concentrations in individual clasts: Complexity of the exposure history in Gobi-Altay range (Mongolia). Geomorphology $135,35-47$.

Weldon, R. J., and Sieh, K. E., 1985. Holocene rate of slip and tentative recurrence interval for large earthquakes on the San Andreas fault, Cajon Pass, southern California. Geological Society of America Bulletin 96, 793-812.

Yang, H., Chen, J., Thompson, J. A., Liu, J., 2012. Optical dating of the 12 May 2008, M 8.0 Wenchuan earthquake-related sediments: Tests of zeroing assumptions. Quaternary Geochronology 10, 273-279. 
1 Table 1. Single-aliquot regenerative-dose protocol for OSL dating (modified from Murray and Wintle, 2000).

\begin{tabular}{clc}
\hline Step & \multicolumn{1}{c}{ Treatment $^{\mathrm{a}}$} & Observed \\
\hline 1 & Give dose, $D_{i}$ & - \\
2 & Preheat $^{\mathrm{a}}\left(260^{\circ} \mathrm{C}\right.$ for $\left.10 \mathrm{~s}\right)$ & - \\
3 & Blue Stimulation for $40 \mathrm{~s}$ at $125^{\circ} \mathrm{C}$ & $L_{i}$ \\
4 & Give test dose, $D_{t}$ & - \\
5 & Cut-heat ${ }^{\mathrm{b}}$ to $220^{\circ} \mathrm{C}$ for $0 \mathrm{~s}$ & - \\
6 & Blue Stimulation for $40 \mathrm{~s}$ at $125^{\circ} \mathrm{C}$ & $T_{i}$ \\
7 & Return to step 1 & - \\
\hline
\end{tabular}

2 ${ }^{\mathrm{a}}$ For the natural sample, $\mathrm{i}=0$, and $\mathrm{D}_{0}=0$.

$3{ }^{\mathrm{b}}$ Aliquot cooled to less than $60^{\circ} \mathrm{C}$ after heating. In step 5, the TL signal from the test dose can be observed, but it is 4 not made in the use of routine applications. 
Table 2. OSL ages of sedimentary layers in the trenched exposure.

\begin{tabular}{ccccccc}
\hline Sample Code & $\begin{array}{c}\text { Depth } \\
(\mathrm{cm})\end{array}$ & $\begin{array}{c}\text { Dose Rate } \\
(\mathrm{Gy} / \mathrm{ka})\end{array}$ & $\begin{array}{c}\text { Equivalent Dose }^{\mathrm{a}} \\
(\mathrm{Gy})\end{array}$ & $\begin{array}{c}\text { Aliquots used } \\
(\mathrm{n} / \mathrm{N})\end{array}$ & $\begin{array}{c}\text { OSL age }^{\mathrm{a}} \\
(\mathrm{ka}, 1 \sigma \mathrm{SE})\end{array}$ & $\begin{array}{c}\text { Fitted age }^{\mathrm{a}, \mathrm{c}} \\
(\mathrm{ka}, 1 \sigma \mathrm{SE})\end{array}$ \\
\hline ABA4-OL-01 & 400 & $3.26 \pm 0.08$ & $53 \pm 1$ & $15 / 16$ & $16.25 \pm 0.50$ & $35.03 \pm 0.50$ \\
ABA4-OL-02 & 385 & $2.93 \pm 0.08$ & $166 \pm 11$ & $16 / 16$ & $56.65 \pm 4.06$ & $33.76 \pm 4.06$ \\
ABA4-OL-03 & 370 & $3.03 \pm 0.08$ & $98 \pm 11$ & $16 / 16$ & $32.34 \pm 3.72$ & $32.49 \pm 3.72$ \\
ABA4-OL-07 & 265 & $3.34 \pm 0.09$ & $121 \pm 12$ & $15 / 16$ & $36.22 \pm 3.72$ & $23.57 \pm 3.72$ \\
ABA4-OL-08 & 265 & $2.83 \pm 0.08$ & $47 \pm 1$ & $16 / 16$ & $16.60 \pm 0.58$ & $23.57 \pm 0.58$ \\
ABA4-OL-10 & 275 & $3.20 \pm 0.10$ & $55 \pm 4$ & $14 / 16$ & $17.18 \pm 1.36$ & $23.15 \pm 1.36$ \\
ABA4-OL-12 & 250 & $3.01 \pm 0.08$ & $39 \pm 2$ & $15 / 16$ & $12.95 \pm 0.74$ & $22.30 \pm 0.74$ \\
ABA4-OL-13 & 240 & $3.22 \pm 0.10$ & $73 \pm 7$ & $16 / 16$ & $22.67 \pm 2.28$ & $21.45 \pm 2.28$ \\
ABA4-OL-14 & 235 & $3.21 \pm 0.10$ & $83 \pm 9$ & $15 / 16$ & $25.85 \pm 2.91$ & $21.02 \pm 2.91$ \\
ABA4-OL-17 & 225 & $3.54 \pm 0.11$ & $62 \pm 4$ & $15 / 16$ & $17.51 \pm 1.25$ & $20.17 \pm 1.25$ \\
ABA4-OL-19 & 140 & $3.48 \pm 0.11$ & $52 \pm 4$ & $16 / 16$ & $14.94 \pm 1.24$ & $12.96 \pm 1.24$ \\
ABA4-OL-21 & 100 & $3.75 \pm 0.11$ & $37 \pm 2$ & $16 / 16$ & $9.86 \pm 0.60$ & $9.56 \pm 0.60$ \\
\hline
\end{tabular}

$8 \quad{ }^{a}$ Central age $\pm 1 \sigma$ standard error.

$9{ }^{\mathrm{b}} \mathrm{n} / \mathrm{N}$ refers to the ratio of (the number of aliquots used for data analysis)/(total number of aliquots loaded in the OSL 10 measurement system).

$11{ }^{\mathrm{c}}$ Fitted ages were calculated based on the linear fitting of depth and measured OSL age of each sedimentary layer 12 (Fig. 5). 
Table 3. ${ }^{10}$ Be exposure ages of the boulders on the foreberg FB6.

\begin{tabular}{|c|c|c|c|c|c|c|c|c|c|c|}
\hline Name & $\begin{array}{l}\text { Latitude } \\
\left({ }^{\circ} \mathrm{N}, \mathrm{DD}\right)\end{array}$ & $\begin{array}{l}\text { Longitude } \\
\left({ }^{\circ} \mathrm{E}, \mathrm{DD}\right)\end{array}$ & $\begin{array}{c}\text { Elevation } \\
\text { (m asl) }\end{array}$ & $\begin{array}{c}\text { Thickness }^{\mathrm{a}} \\
(\mathrm{cm})\end{array}$ & $\begin{array}{l}\text { Shielding } \\
\text { factor }\end{array}$ & $\begin{array}{l}\text { Quartz } \\
\text { (g) }\end{array}$ & $\begin{array}{c}\text { Be carrier } \\
(\mathrm{g})\end{array}$ & ${ }^{10} \mathrm{Be} /{ }^{9} \mathrm{Be}^{\mathrm{c}, \mathrm{d}}\left(10^{-13}\right)$ & $\begin{array}{c}{ }^{10} \mathrm{Be} \\
\text { concentration }{ }^{\mathrm{d}, \mathrm{e}} \\
\left(10^{5} \text { atoms } / \mathrm{g}\right)\end{array}$ & $\begin{array}{c}\text { Exposure } \\
\text { aged }^{\mathrm{d}, \mathrm{f}} \\
(\mathrm{ka})\end{array}$ \\
\hline $\mathrm{ABC} 001$ & 44.63845 & 102.13025 & 1574 & 6 & 0.9985 & 15.9652 & 0.3921 & $3.465 \pm 0.021$ & $5.60 \pm 0.07$ & $40.7 \pm 3.2$ \\
\hline $\mathrm{ABC} 002$ & 44.63835 & 102.13036 & 1575 & 4 & 0.9986 & 9.8940 & 0.3911 & $2.360 \pm 0.012$ & $6.11 \pm 0.07$ & $43.8 \pm 3.5$ \\
\hline $\mathrm{ABC} 004$ & 44.63833 & 102.12856 & 1575 & 4 & 0.9985 & 5.6309 & 0.3843 & $16.477 \pm 0.534$ & $74.40 \pm 2.53$ & $612.7 \pm 61.6$ \\
\hline
\end{tabular}

a Tops of the exposed boulder surfaces.

${ }^{\mathrm{b}}$ Density of rock $\left(2.7 \mathrm{~g} / \mathrm{cm}^{3}\right)$ was used.

${ }^{\mathrm{c}}$ Ratios of ${ }^{10} \mathrm{Be} /{ }^{9} \mathrm{Be}$ were normalized with 07KNSTD reference sample 5-1 $\left(2.71 \times 10^{-11} \pm 1.09 \times 10^{-13}\right)$ of Nishiizumi et al. $(2007)$ and ${ }^{10} \mathrm{Be}$ half-life of $1.38 \times 10^{6}(\mathrm{Chmeleff}$ et al., 2010; Korschinek et al., 2010).

${ }^{\mathrm{d}}$ Uncertainties are calculated at the $1 \sigma$ confidence level.

${ }^{\mathrm{e}}$ A mean value of process blank samples $\left(2.68 \times 10^{-15} \pm 1.12 \times 10^{-15} ; \mathrm{n}=2\right)$ was used for correction of background.

${ }^{\mathrm{f}}$ Ages are calculated assuming zero erosion via the CRONUS-Earth online calculator (version 3.0) of Balco et al. (2008) with scaling factors of Stone (2000). 


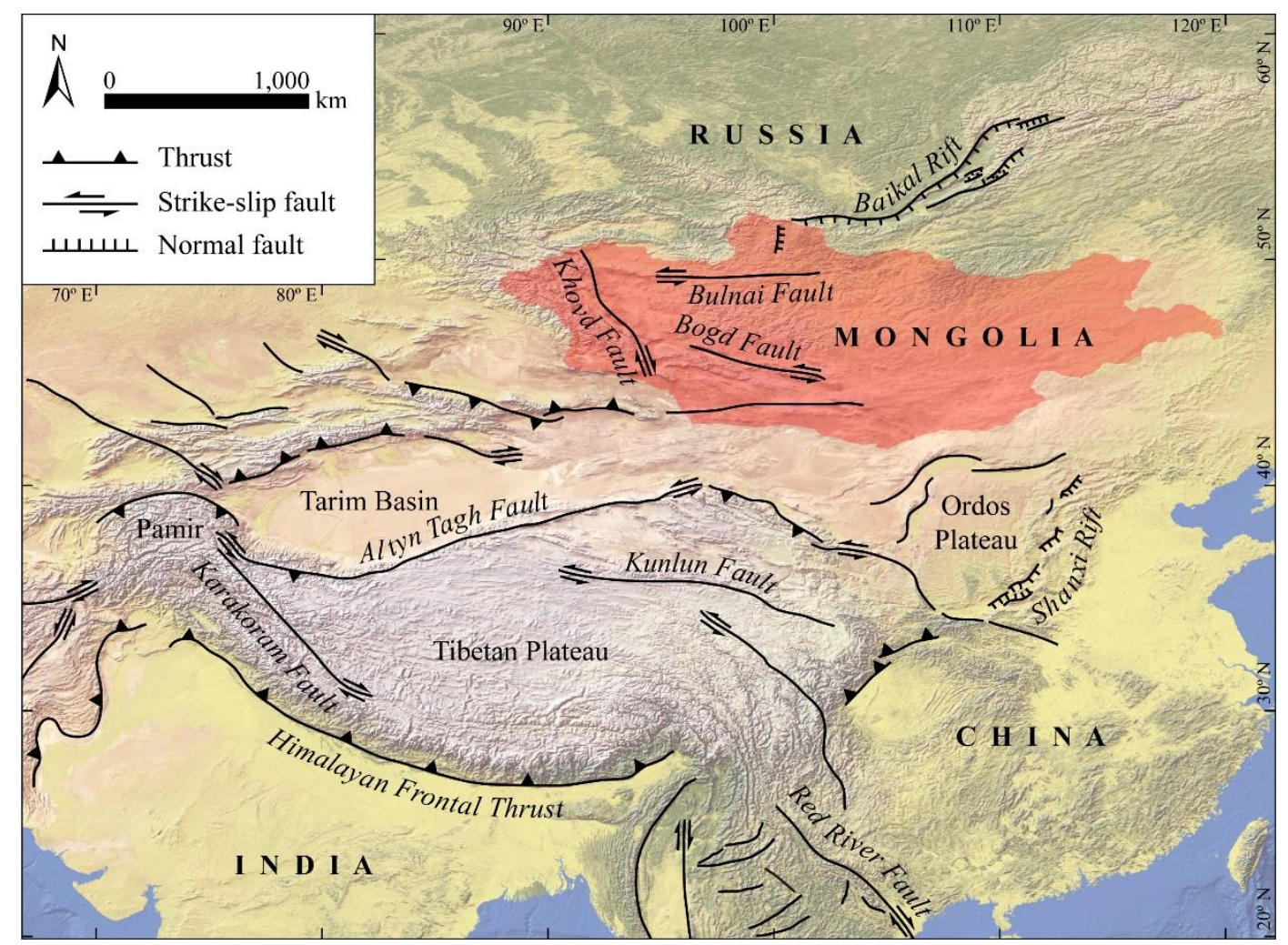

Figure 1. Simplified tectonic map of central Asia. The Bogd Fault formed along the slip line made by the collision between the Eurasian and the Indian plates (modified from Tapponnier and Molnar, 1976). 


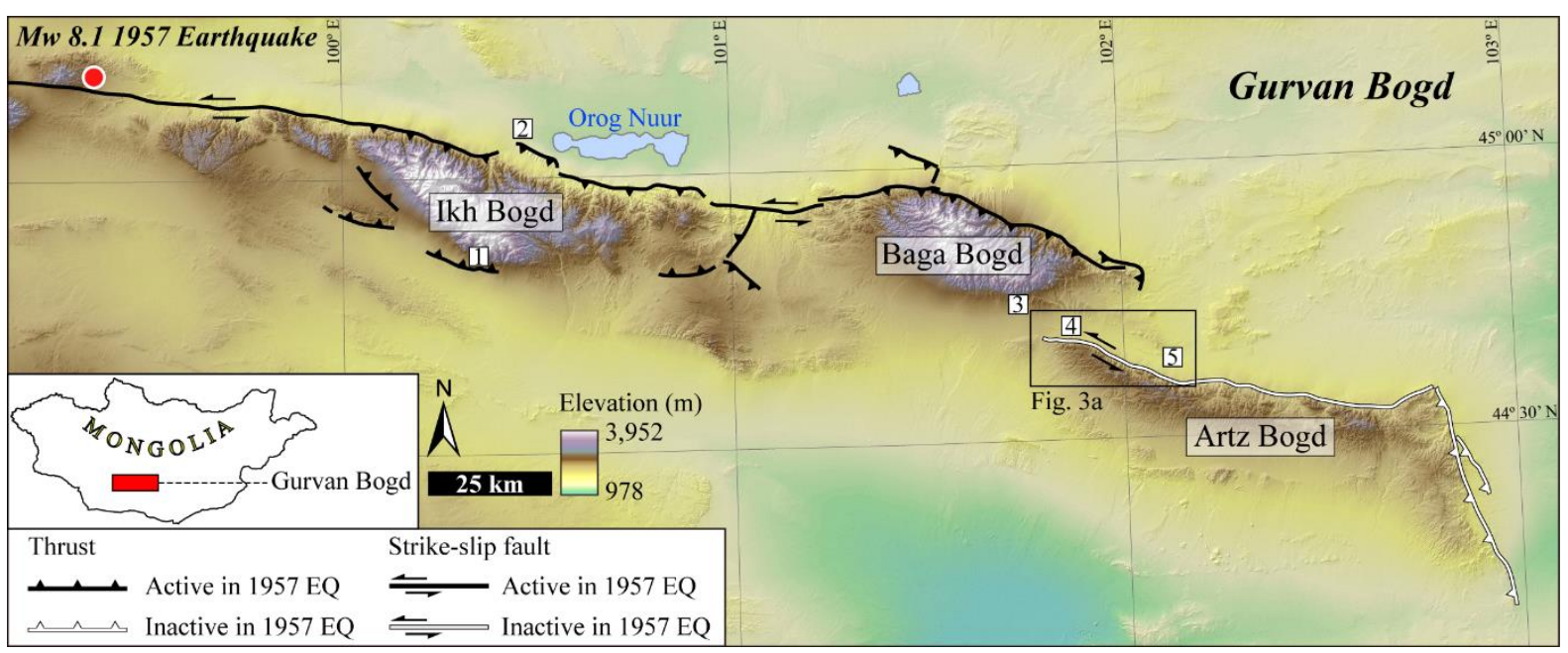

Figure 2. Map of the study area (Gurvan Bogd) and epicentre of the 1957 earthquake in the Gobi-Altay, Mongolia. The numbers (1 through 5) in the small rectangle indicate the vertical slip rates reported from previous studies. 1: $0.14 \pm 0.03 \mathrm{~m} / \mathrm{kyr}$ (Ritz et al., 2003), $0.19 \pm 0.05$ to $0.23 \pm 0.05 \mathrm{~m} / \mathrm{kyr}$ (Vassallo et al., 2005), $0.12 \pm 0.02$ to 0.13 $\pm 0.02 \mathrm{~m} / \mathrm{kyr}$ (Vassallo et al., 2005); 2: $0.10 \pm 0.01 \mathrm{~m} / \mathrm{kyr}$ (Hanks et al., 1997); 3: $0.11 \pm 0.03 \mathrm{~m} / \mathrm{kyr}$ (Carretier, 2000); 4: $0.13 \pm 0.01 \mathrm{~m} / \mathrm{kyr}$ (Vassallo et al., 2005); 5: $0.05 \pm 0.003 \mathrm{~m} / \mathrm{kyr}$ (Owen et al., 1999). 

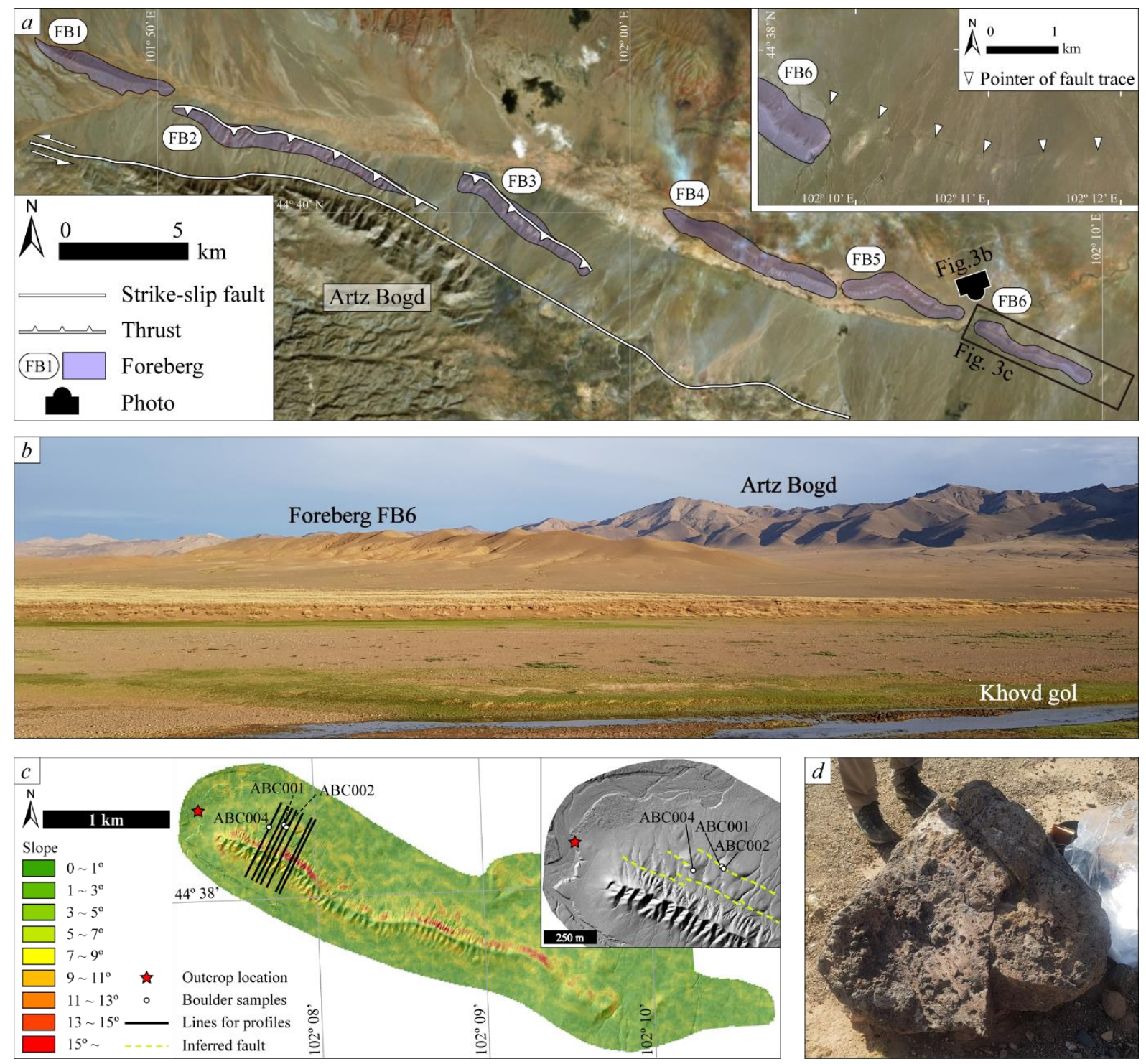

Figure 3. Detailed maps of the study area. (a) Foreberg development on the alluvial fans that are sourced from the Artz Bogd. (b) Image of foreberg FB6, with the Artz Bogd in the background. The approximate camera angle for this image is shown in Fig. 3a. (c) Slope analysis around foreberg F6 based on the 12.5-m resolution ALOS PALSAR DEM. The locations of the trenched outcrop (red star), ${ }^{10} \mathrm{Be}$ surface exposure dating sites (white circles) and cross-sectional profiles for deriving the alluvial fan slope (black lines) are shown. The inset image is a hillshade DEM of the study area that was constructed from $\sim 7000$ drone images $(50-\mathrm{cm}$ resolution); the dashed yellow lines denote inferred faults. (d) Image of a large ( $>1 \mathrm{~m}$ ) boulder (ABC004) that was sampled for ${ }^{10} \mathrm{Be}$ surface exposure dating. 
$a$

Depth OSL Layer

age

(cm) (ka) number
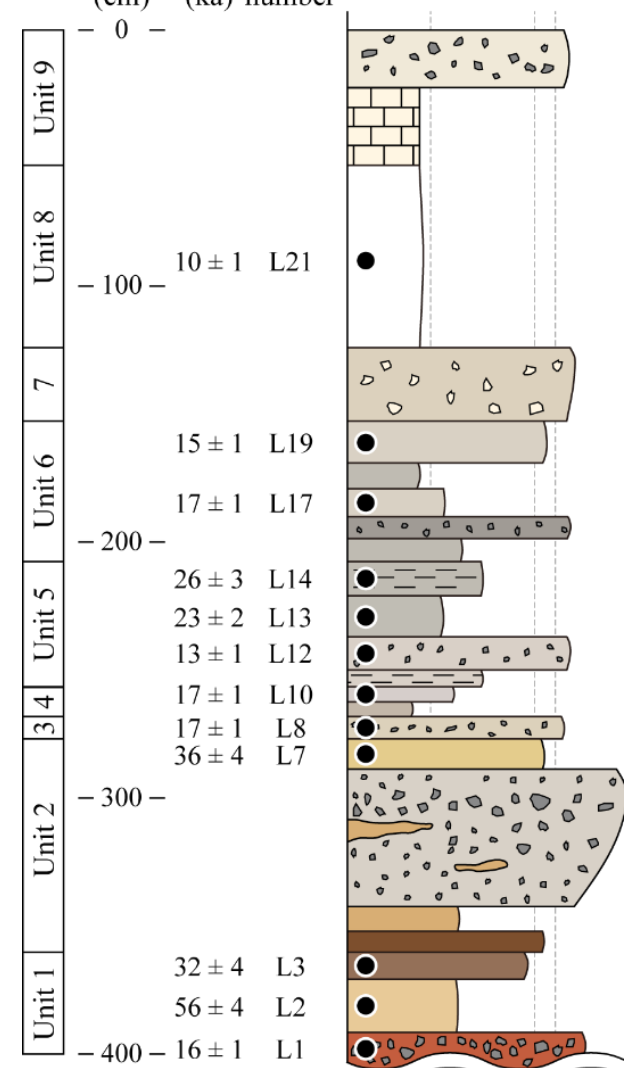

○-
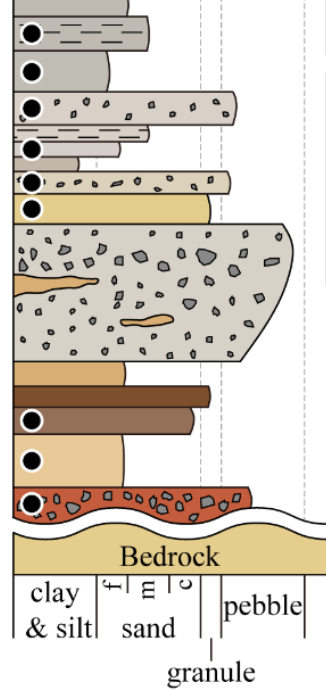

$b$

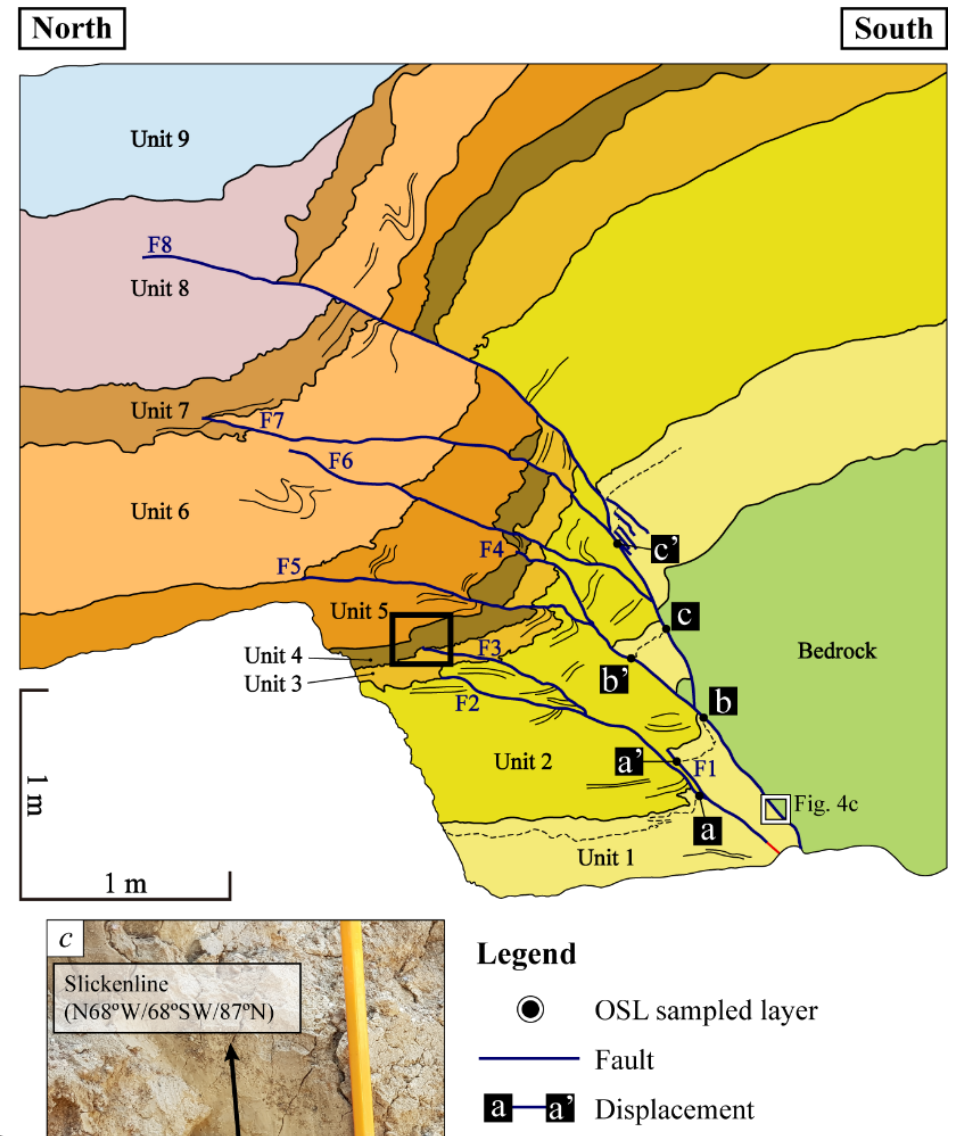

Layer measured displacement

N55 Bedding

-..-. Strike

Slickenline

Figure 4. Information on the trenched exposure and OSL dating of sedimentary layers. (a) Stratigraphic section of the sedimentary layers in the trenched exposure. (b) Simplified sketch of the faulted outcrop. The black box highlights an example of deformation in the unit above a terminated fault tip. The white box identifies the location of the image in Fig. 4c. (c) Image of a bedrock slickenline, which indicates sub-vertical slip. 


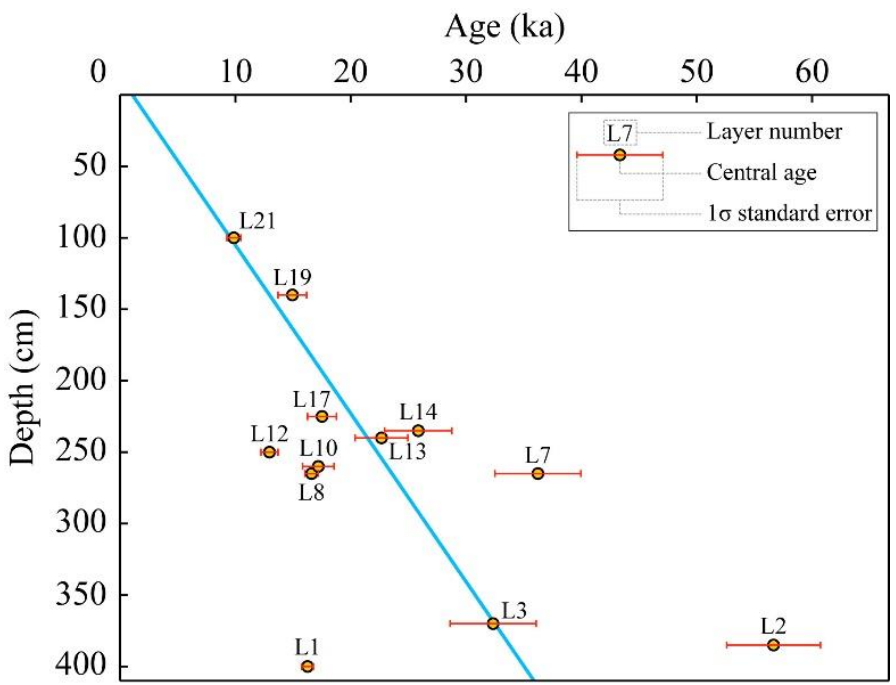

Figure 5. Linear fit of the OSL ages, with $\mathrm{R}^{2}=0.333$. The measured and fitted ages are listed in Table 2 . 
$a$

Event sequence

Earthquake

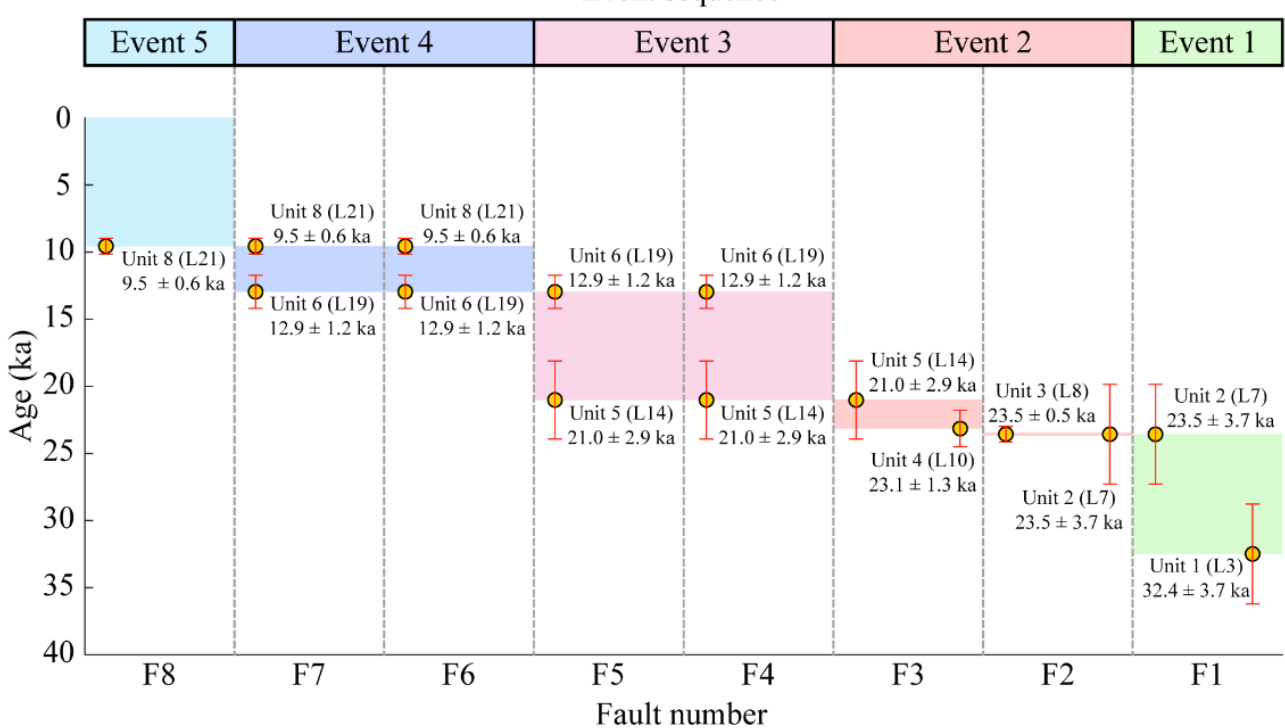

Reccurence Interval

$4.78 \mathrm{ka}$

$11.06 \mathrm{ka}-6.28 \mathrm{kyrs}$

$16.99 \mathrm{ka}$ -

$5.93 \mathrm{kyrs}$

$22.29 \mathrm{ka} 5.30 \mathrm{kyrs}$

$5.74 \mathrm{kyrs}$

$28.03 \mathrm{ka}^{-}$

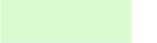

Fault number

Figure 6. (a) Sequence of faulting events and (b) deduced earthquake recurrence interval in the study area. The recurrence interval was based on the central age of each event (see Table 2). 

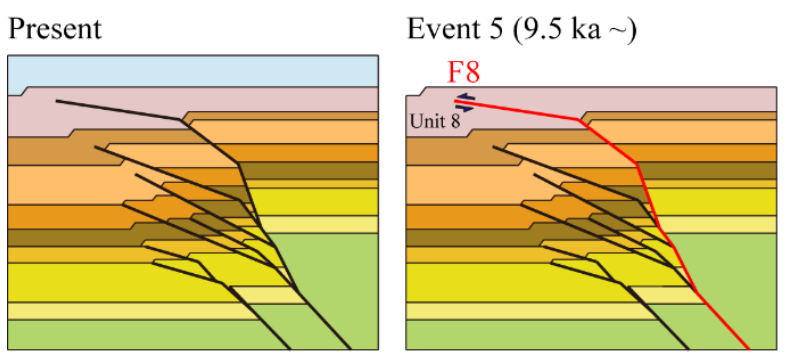

$9.5 \mathrm{ka}$

Event 4-2 (12.9 9.5 ka)

$12.9 \sim 9.5 \mathrm{ka}$

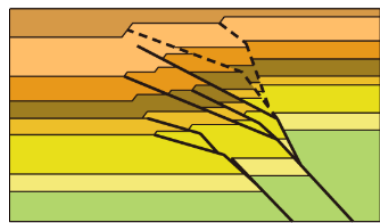

$21.0 \mathrm{ka}$

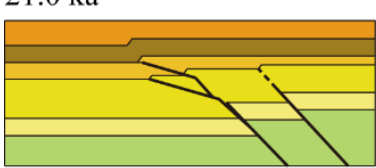

$23.5 \mathrm{ka}$

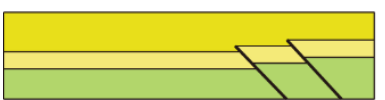

Event $4-1(12.9 \sim 9.5 \mathrm{ka})$

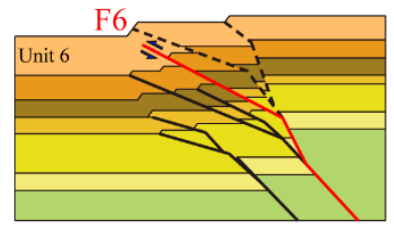

Event 2-2 (23.1 21.0 ka)

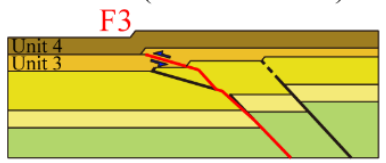

Event $1(32.4 \sim 23.5 \mathrm{ka})$

F1

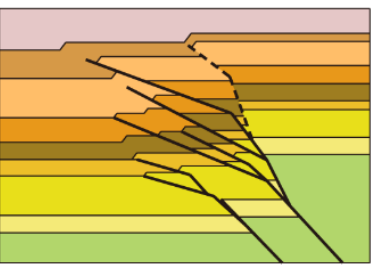

$12.9 \mathrm{ka}$

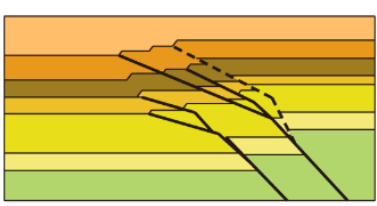

$23.5 \sim 23.1 \mathrm{ka}$

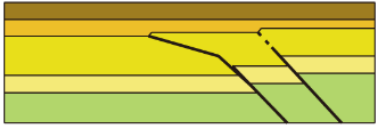

$32.4 \mathrm{ka}$

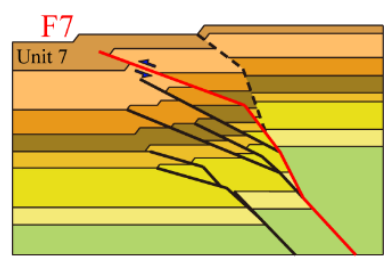

Event $3(21.0 \sim 12.9 \mathrm{ka})$

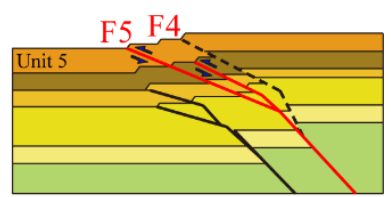

Event 2-1 (23.5 ka)

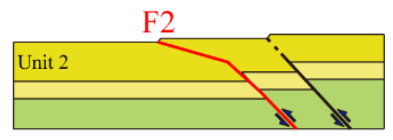

Initial stage
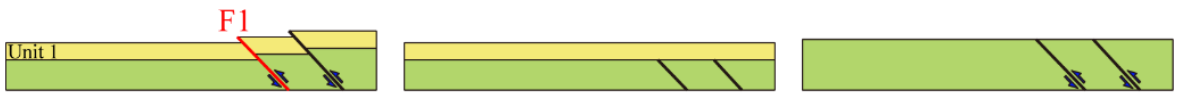

\begin{tabular}{|c|c|c|c|c|c|}
\hline Bedrock & Unit 1 & Unit 2 & Unit 3 & Unit 4 & Unit 5 \\
\hline Unit 6 & Unit 7 & Unit 8 & Unit 9 & Fault & ----. Inferred fault \\
\hline
\end{tabular}

Figure 7. Restoration of deformation in the trenched exposure in reverse order. The best-fit OSL ages are provided for each panel. 
Elevation (m)

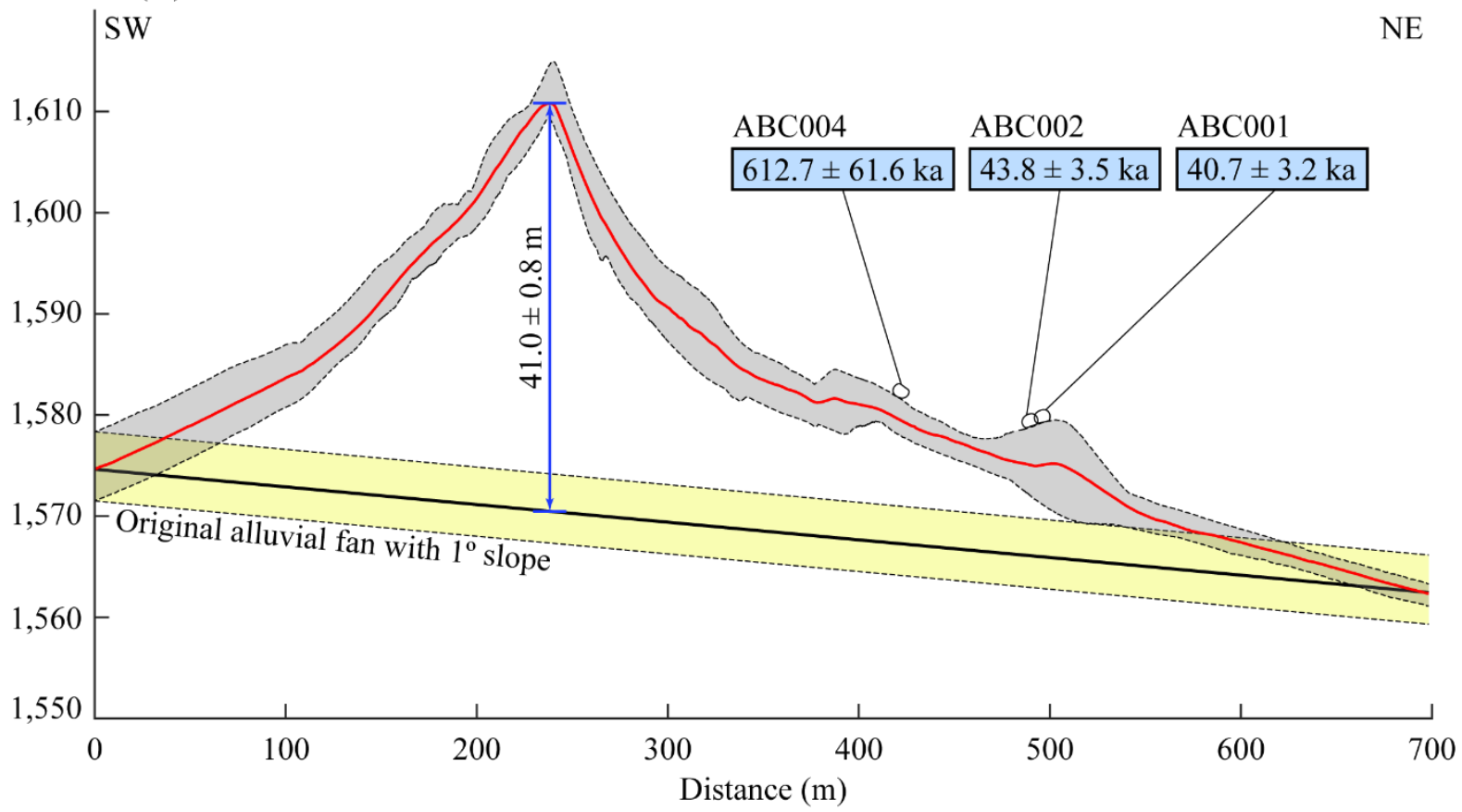

Figure 8. Vertical displacement of the alluvial fan surface due to thrusting and ${ }^{10} \mathrm{Be}$ surface exposure ages of the boulder samples from foreberg FB6. Shaded regions along each curve represent the surface elevation range along the cross-sectional profiles. 


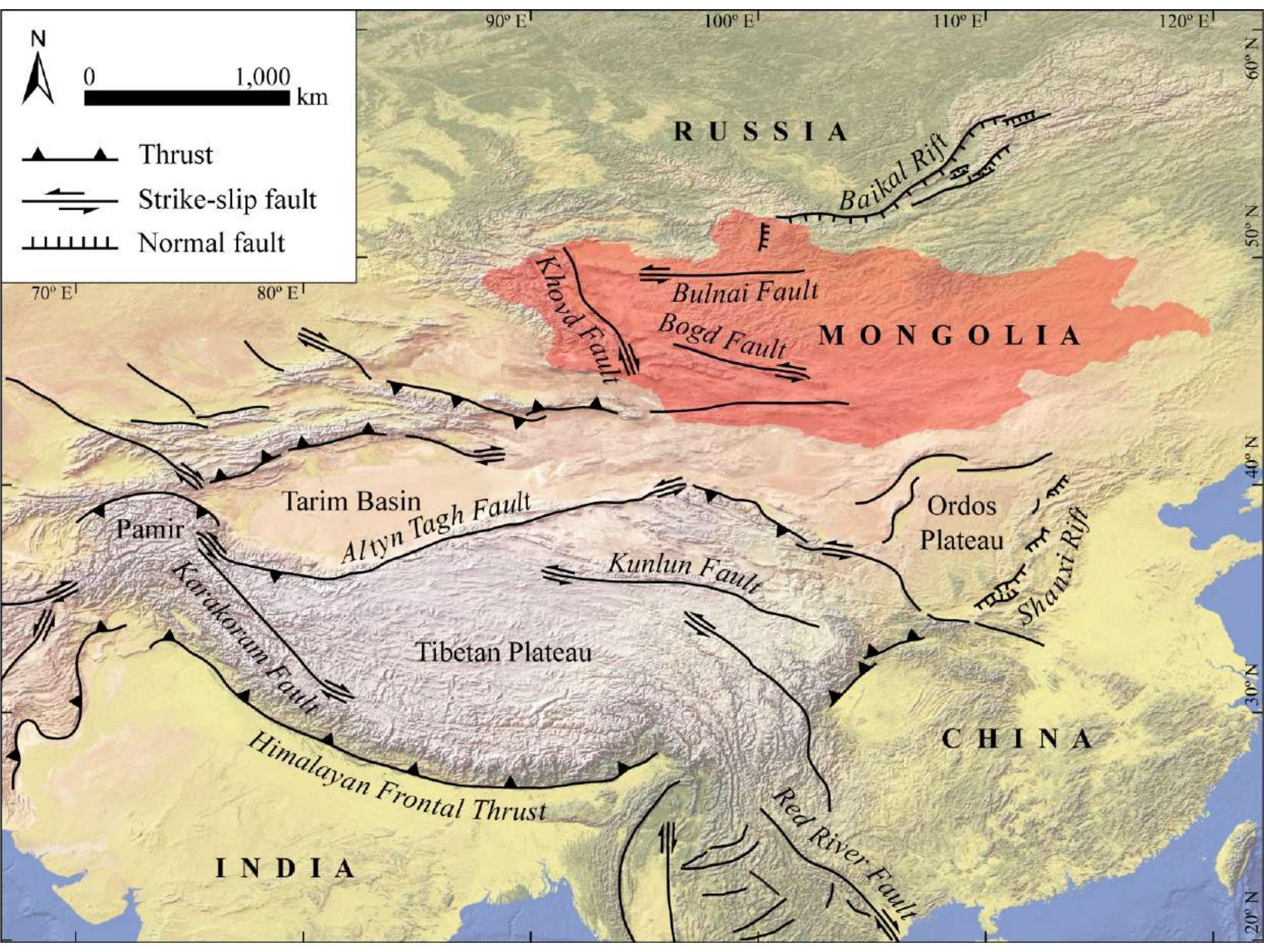




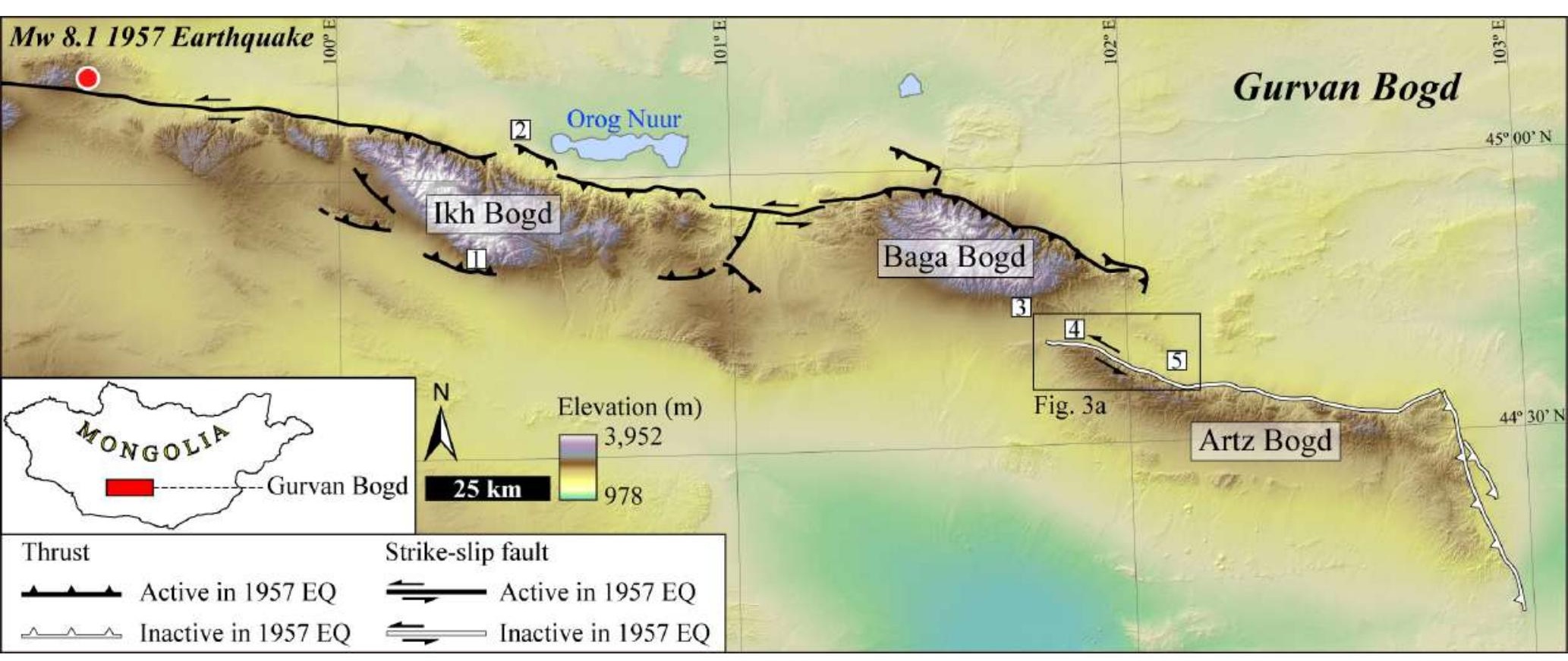


$a$

Depth OSL Layer age

(cm) (ka) number
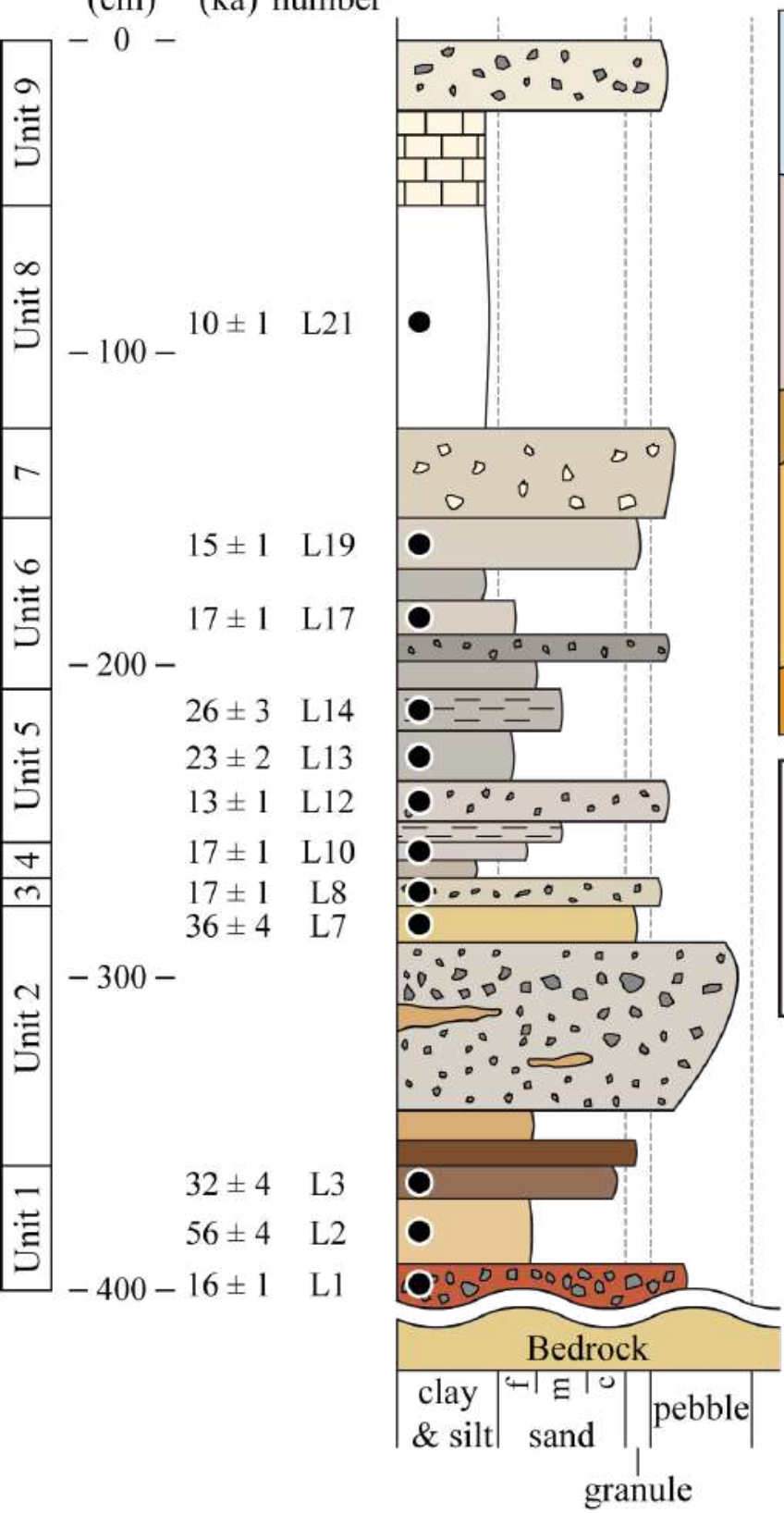

b

North

South
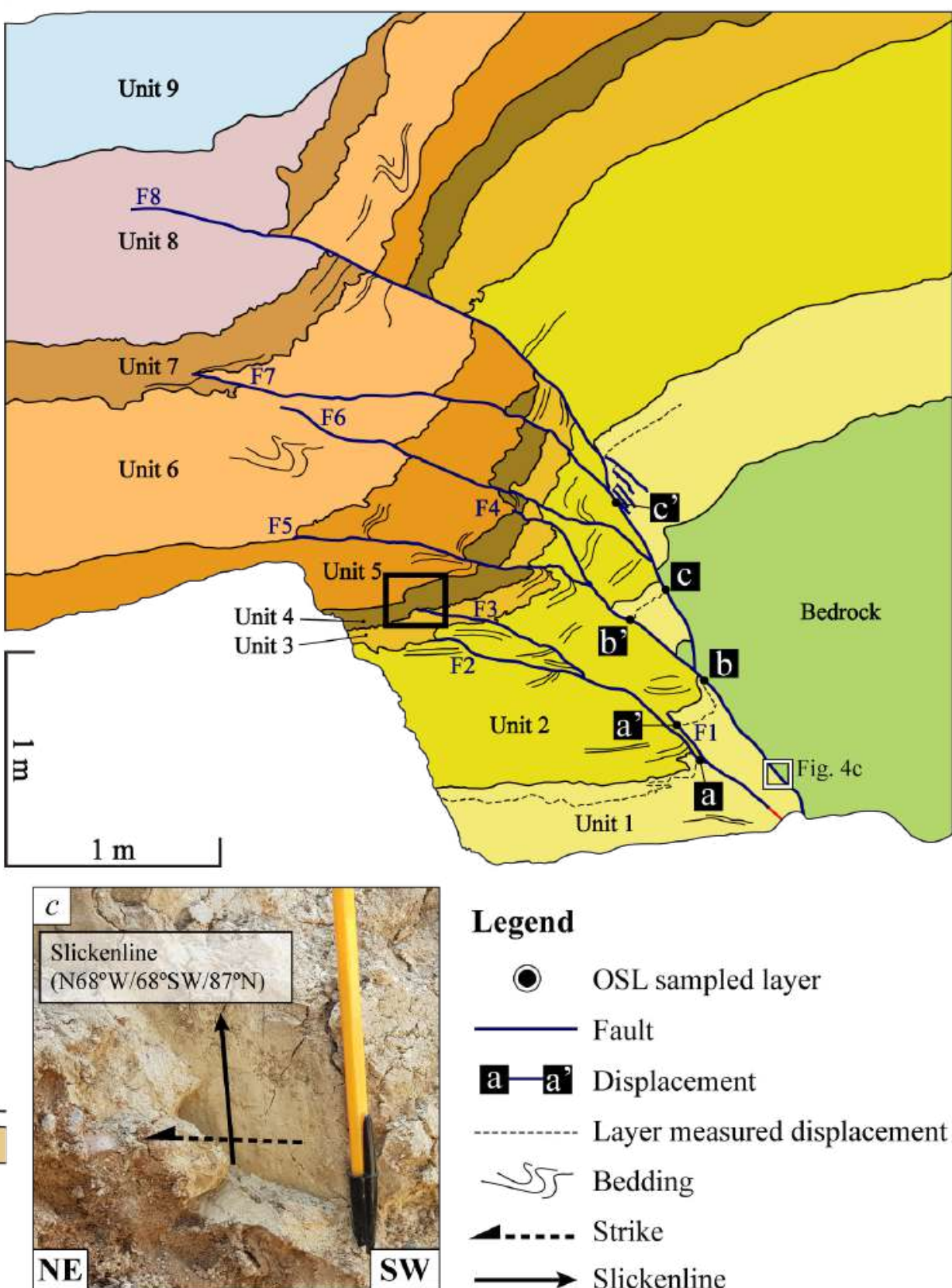

\section{Legend}

- OSL sampled layer

Fault

a-a Displacement

Layer measured displacement

N55 Bedding

4..... Strike

Slickenline 


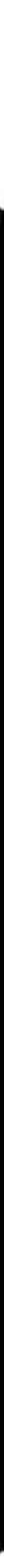


Event sequence

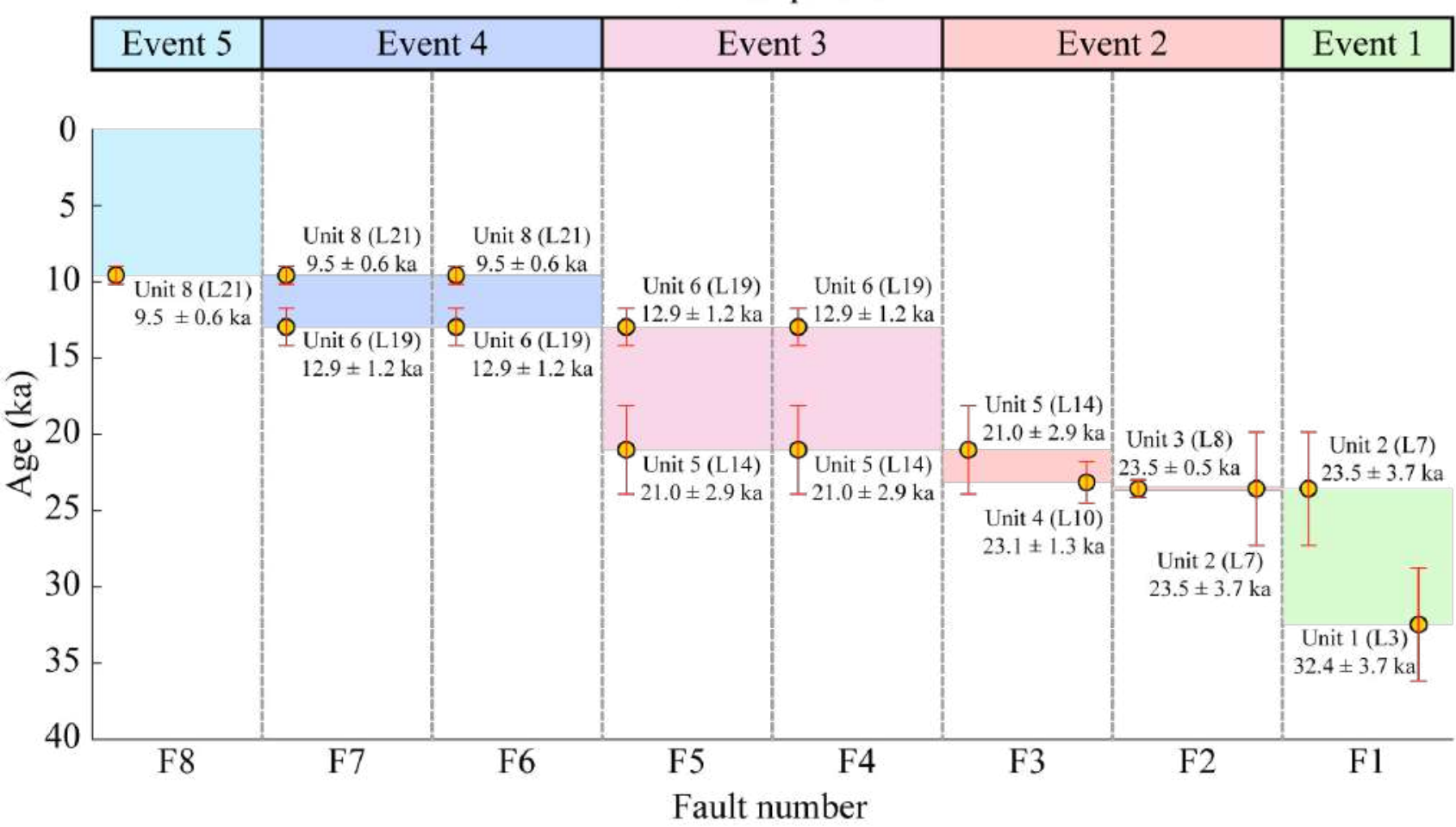

$b$

Earthquake

Reccurence Interval

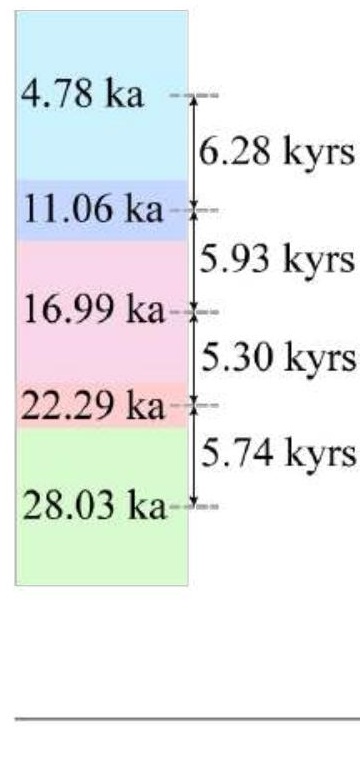




\section{Present}

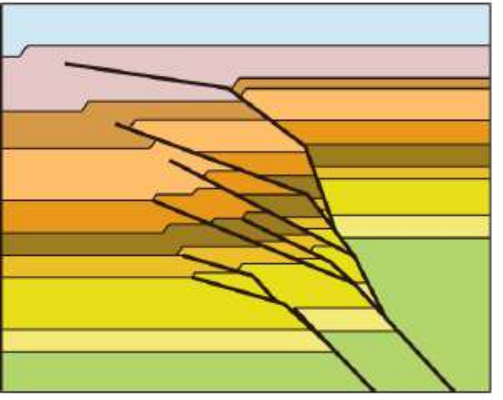

\section{$12.9 \sim 9.5 \mathrm{ka}$}

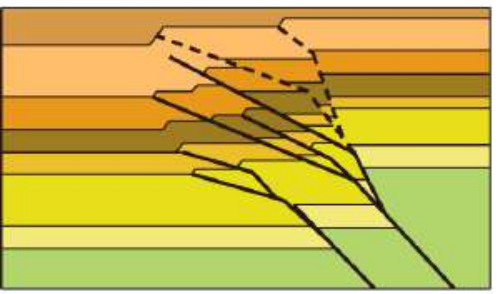

\section{$21.0 \mathrm{ka}$}

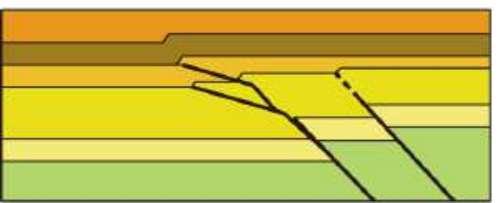

$23.5 \mathrm{ka}$

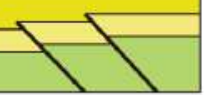

Event 5 (9.5 ka $\sim)$

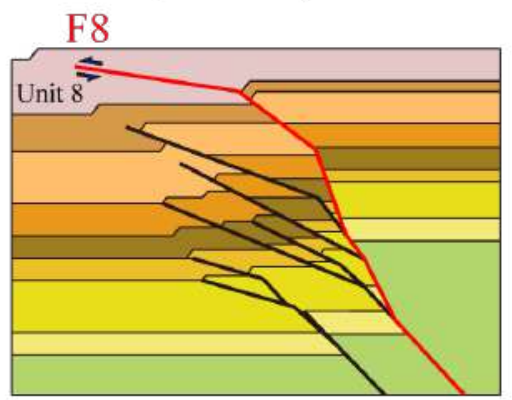

Event 4-1 (12.9 9.5 ka)

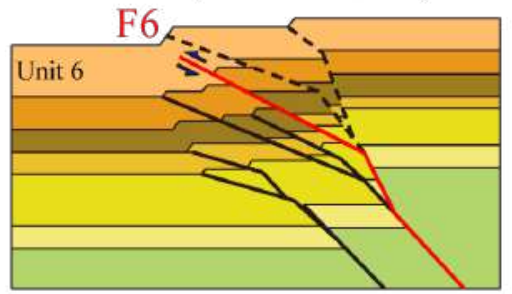

Event 2-2 (23.1 21.0 ka)

F3

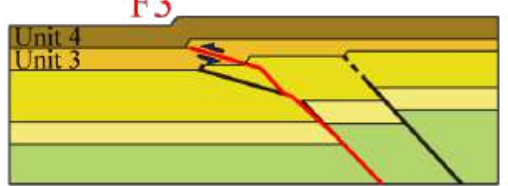

Event $1(32.4 \sim 23.5 \mathrm{ka})$

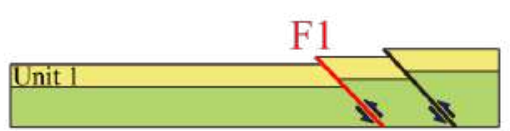

$9.5 \mathrm{ka}$

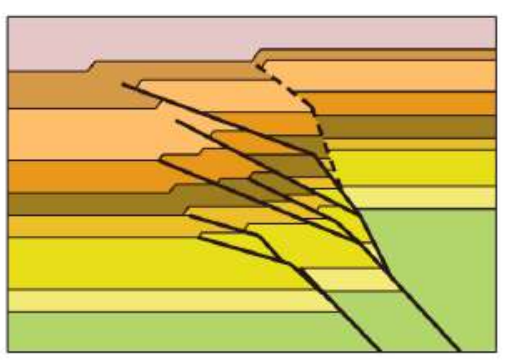

$12.9 \mathrm{ka}$

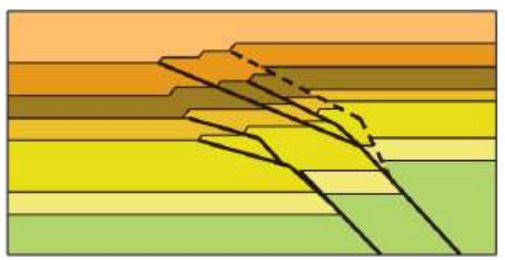

$23.5 \sim 23.1 \mathrm{ka}$

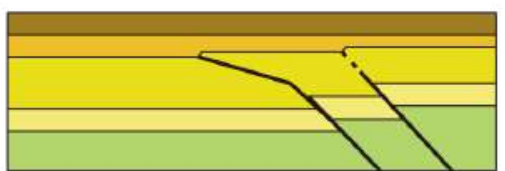

$32.4 \mathrm{ka}$

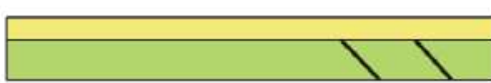

Event 4-2 (12.9 9.5 ka)

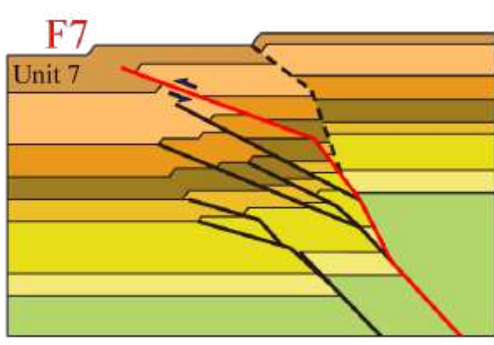

Event $3(21.0 \sim 12.9 \mathrm{ka})$

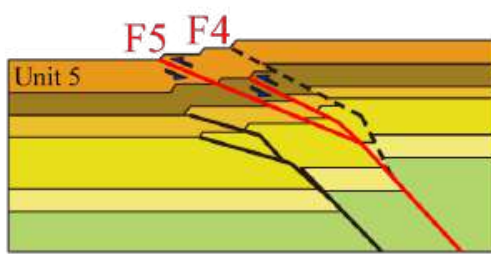

Event 2-1 (23.5 ka)

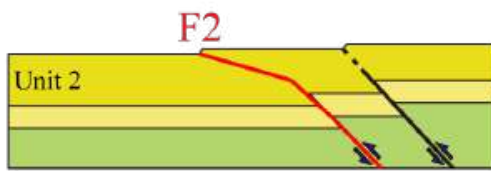

Initial stage

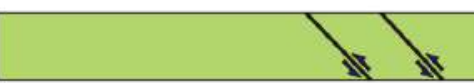

\begin{tabular}{|c|c|c|c|c|c|}
\hline Bedrock & Unit 1 & Unit 2 & Unit 3 & Unit 4 & Unit 5 \\
\hline Unit 6 & Unit 7 & Unit 8 & Unit 9 & EFault & $-\cdots$ Inferred fa \\
\hline
\end{tabular}


Elevation (m)

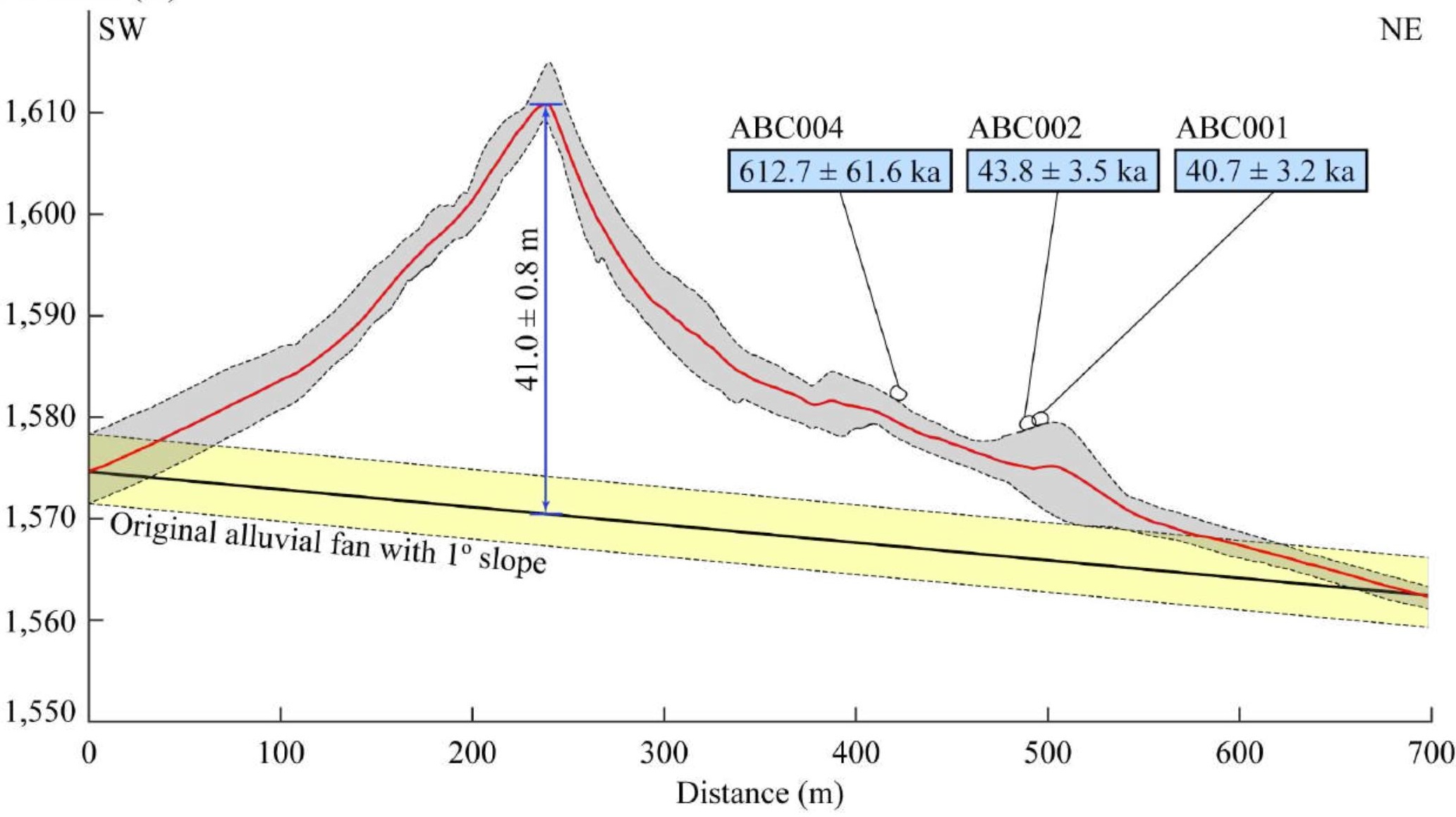

